\title{
Identification of a small molecule
} as inducer of ferroptosis and apoptosis through ubiquitination of GPX4 in triple negative breast cancer cells

Yahui Ding ${ }^{1}$, Xiaoping Chen ${ }^{1}$, Can Liu ${ }^{1}$, Weizhi Ge' ${ }^{1}$ Qin Wang ${ }^{1}$, Xin Hao ${ }^{1}$, Mengmeng Wang ${ }^{2}$, Yue Chen ${ }^{\text {** }}$ and Quan Zhang ${ }^{1 *}$ (iD

\begin{abstract}
Background: TNBC is the most aggressive breast cancer with higher recurrence and mortality rate than other types of breast cancer. There is an urgent need for identification of therapeutic agents with unique mode of action for overcoming current challenges in TNBC treatment.

Methods: Different inhibitors were used to study the cell death manner of DMOCPTL. RNA silencing was used to evaluate the functions of GPX4 in ferroptosis and apoptosis of TNBC cells and functions of EGR1 in apoptosis. Immunohistochemical assay of tissue microarray were used for investigating correlation of GPX4 and EGR1 with TNBC. Computer-aided docking and small molecule probe were used for study the binding of DMOCPTL with GPX4.

Results: DMOCPTL, a derivative of natural product parthenolide, exhibited about 15-fold improvement comparing to that of the parent compound PTL for TNBC cells. The cell death manner assay showed that the anti-TNBC effect of DMOCPTL mainly by inducing ferroptosis and apoptosis through ubiquitination of GPX4. The probe of DMOCPTL assay indicated that DMOCPTL induced GPX4 ubiquitination by directly binding to GPX4 protein. To the best of our knowledge, this is the first report of inducing ferroptosis through ubiquitination of GPX4. Moreover, the mechanism of GPX4 regulation of apoptosis is still obscure. Here, we firstly reveal that GPX4 regulated mitochondria-mediated apoptosis through regulation of EGR1 in TNBC cells. Compound 13, the prodrug of DMOCPTL, effectively inhibited the growth of breast tumor and prolonged the lifespan of mice in vivo, and no obvious toxicity was observed.

Conclusions: These findings firstly revealed novel manner to induce ferroptosis through ubiquitination of GPX4 and provided mechanism for GPX4 inducing mitochondria-mediated apoptosis through up-regulation of EGR1 in TNBC cells. Moreover, compound $\mathbf{1 3}$ deserves further studies as a lead compound with novel mode of action for ultimate discovery of effective anti-TNBC drug.
\end{abstract}

Keywords: GPX4, Ubiquitination, EGR1, Ferroptosis, Triple negative breast cancer

*Correspondence: yuechen@nankai.edu.cn; zhangquan@nankai.edu.cn; zhangquan612@163.com

1 State Key Laboratory of Medicinal Chemical Biology, College of Pharmacy and Tianjin Key Laboratory of Molecular Drug Research, Nankai University, Haihe Education Park, 38 Tongyan Road, Tianjin 300353, People's Republic of China

Full list of author information is available at the end of the article

\section{Introduction}

Ferroptosis is a new form of programmed cell death characterized by the accumulation of iron-dependent lipid peroxides, and is morphologically, biochemically, and genetically distinct from apoptosis, necrosis, and autophagy [1]. In recent years, more and more research original author(s) and the source, provide a link to the Creative Commons licence, and indicate if changes were made. The images or other third party material in this article are included in the article's Creative Commons licence, unless indicated otherwise in a credit line to the material. If material is not included in the article's Creative Commons licence and your intended use is not permitted by statutory regulation or exceeds the permitted use, you will need to obtain permission directly from the copyright holder. To view a copy of this licence, visit http://creativecommons.org/licenses/by/4.0/. The Creative Commons Public Domain Dedication waiver (http://creativeco mmons.org/publicdomain/zero/1.0/) applies to the data made available in this article, unless otherwise stated in a credit line to the data. 
revealed that ferroptosis was implicated in various human diseases, including Alzheimer's, Parkinson's and Huntington's diseases, stroke, periventricular leukomalacia (PVL), intracerebral hemorrhage, kidney degeneration [2,3]. Moreover, emerging evidence indicated that ferroptosis may also have a tumor-suppressor function for cancer therapy. It was reported that many cancer cells, such as liver cancer, diffuse large B cell lymphomas (DLBCL), renal cell carcinoma, gastric cancer, rhabdomyosarcoma, ovarian cancer cells, are susceptible to ferroptosis $[4,5]$. Small molecule ferroptosis inducers had a strong inhibition of tumor growth and enhanced the sensitivity of chemotherapeutic drugs [6]. Combination of chemotherapeutic drugs such as tmozolomide, cisplatin, doxorubicin with ferroptosis inducer erastin resulted in a remarkable synergistic effect on tumor treatment [3]. Therefore, induction of ferroptosis has become a novel potential therapeutic strategy for cancer therapy [7-12].

Breast cancer is the most commonly being diagnosed cancer and the leading cause of cancer death for women. Worldwide, there are about 2.1 million newly diagnosed female breast cancer cases, and the incidence and mortality of female breast cancer is $24.2 \%$ and $15 \%$, respectively, in 2018 [13]. Breast cancer accounts for 30\% all new cancer diagnoses in women in USA [14]. Although 5 -year relative survival rate for breast cancer is $90 \%$ in USA [14], the prognosis is still far from satisfactory, especially for triple-negative breast cancer (TNBC). TNBC is the most aggressive breast cancer with higher recurrence and mortality rate than other types of breast cancer [15]. TNBC represents $15-20 \%$ of breast carcinomas and is characterized by lack of expression of estrogen receptors (ER), progesterone receptors (PR) and human epidermal growth factor receptor 2 (HER-2) [16, 17]. TNBC patients cannot benefit from targeted therapy, such as endocrine or anti-HER2 therapy and chemotherapy is still the only validated therapy option for treatment of TNBC in clinical practice [18]. Therefore, there is an urgent need for identification of therapeutic agents with unique mode of action for overcoming current challenges in TNBC treatment.

It was reported that ferroptosis inducer erastin could selectively target MDA-MB-231 cells and efficiently induce ferroptosis in TNBC cells [19]. Sulfasalazine could induce ferroptosis in breast cancer cells with low ER expression [20]. Combination of siramesine and lapatinib induced ferroptosis in MDA-MB-231 and SKBR3 cells [21]. Kufe et al., identified that targeting MUC1-C/ $\mathrm{xCT}$ signaling pathway induced ferroptosis of TNBC cells [22]. Lee and Tseng et al., reported that cystine starvation could trigger ferroptosis through $\mathrm{CHAC} 1$ degradation of glutathione via GCN2-eIF2 $\alpha$-ATF4 pathway in human
TNBC cells [23]. Therefore, inducing ferroptosis is a new effective strategy for treatment of TNBC.

Sesquiterpene lactones (SLs) have attracted extensive attention because of their potent bioactivity, such as anti-cancer, anti-inflammatory and anti-malaria [24, 25]. Parthenolide (1, PTL, Fig. 1), a prominent germacranetype SL, showed promising anti-cancer property. Nevertheless, PTL has some disadvantages, such as poor oral bioavailability, unstable under chemical and physiological conditions and poor water solubility [26, 27]. DMAPT, a derivative of PTL, effectively increased the water solubility and oral bioavailability, which has advanced into a phase I clinical trial for treatment of acute myeloid leukemia (AML) [25]. Recently, we developed the other PTL derivative, ACT001, to be in clinical trial in Australia and China for treatment of glioblastoma [28].

As previous studies suggested that GPX4 inhibition induced ferroptosis [29], we rationalized that an alternative way to lead to cancer cell death by inducing ferroptosis would be through ubiquitination of GPX4 to reduce abundance of GPX4. In this study, we revealed a PTL derivative (2, DMOCPTL, Fig. 2) as an inducer of ferroptosis and apoptosis through ubiquitination of GPX4 and a potential therapeutic agent for TNBC. To the best our knowledge, herein, this is the first report of inducing ferroptosis through ubiquitination of GPX4.

\section{Materials and methods \\ Chemistry}

Synthesis of compound 4. To a solution of $3(500 \mathrm{mg}$, $2.74 \mathrm{mmol})$ and $\mathrm{TBSCl}(455 \mathrm{mg}, 3.0 \mathrm{mmol})$ in $\mathrm{CH}_{2} \mathrm{Cl}_{2}$ was added imidazole $(204 \mathrm{mg}, 3.0 \mathrm{mmol})$ at $0{ }^{\circ} \mathrm{C}$. The mixture was stirred overnight, quenched with $\mathrm{NH}_{4} \mathrm{Cl}$, and extracted with $\mathrm{CH}_{2} \mathrm{Cl}_{2}$. The $\mathrm{CH}_{2} \mathrm{Cl}_{2}$ layer was dried over anhydrous $\mathrm{Na}_{2} \mathrm{SO}_{4}$ and concentrated under reduced pressure to provide 4 (731 $\mathrm{mg}, 2.47 \mathrm{mmol}$, yield $90 \%$ ).

Synthesis of compound 5. To a solution of trimethyl phosphonoacetate $(1.48 \mathrm{~mL}, 9.17 \mathrm{mmol})$ in anhydrous THF $(20 \mathrm{~mL})$ was added LiHMDS $(1.0 \mathrm{M}$, $9.17 \mathrm{~mL}, 9.17 \mathrm{mmol})$ at $-20{ }^{\circ} \mathrm{C}$. After $1.5 \mathrm{~h}$, the mixture was cooled to $-78{ }^{\circ} \mathrm{C}$. Compound 4 (1.36 g, $4.59 \mathrm{mmol}$ ) in THF was added to the mixture. The reaction mixture was quenched with saturated $\mathrm{NaCl}$ and extracted with ethylacetate. The organic layer was

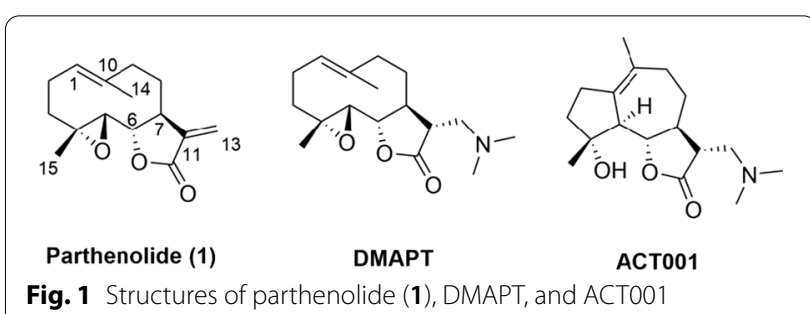




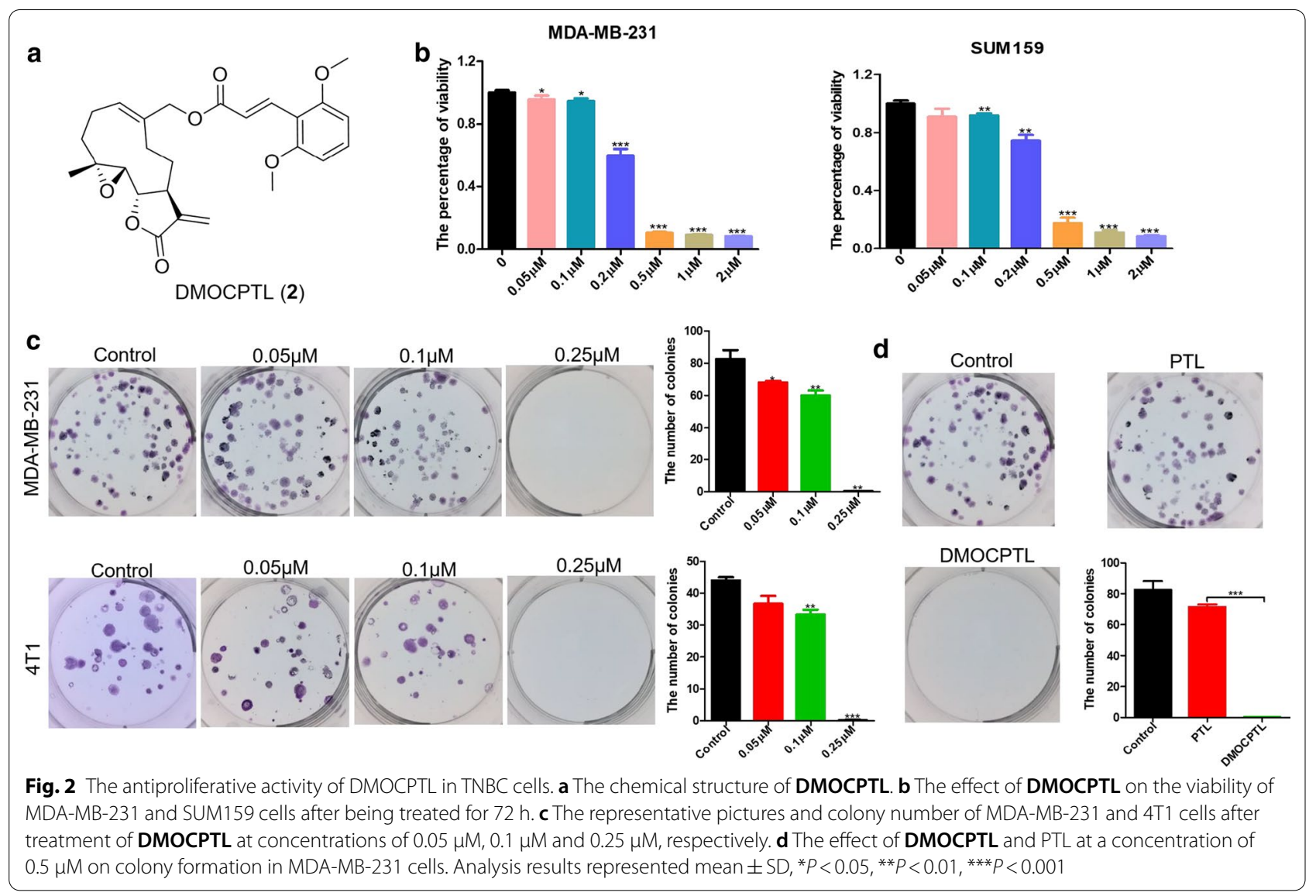

dried over anhydrous $\mathrm{Na}_{2} \mathrm{SO}_{4}$ and concentrated under reduced pressure to give a crude oil. The resulting oil was dissolved in THF, which was added TBAF in THF $(5 \mathrm{~mL}, 1 \mathrm{~N})$. After $12 \mathrm{~h}$, the reaction was quenched with $\mathrm{NH}_{4} \mathrm{Cl}$, extracted with ethylacetate. The organic layer was dried over anhydrous $\mathrm{Na}_{2} \mathrm{SO}_{4}$ and concentrated under reduced pressure to give an oil, which was purified with silica gel column chromatography to provide a white solid 5 (915 mg, yield 84\%). ${ }^{1} \mathrm{H}$ NMR $\left(400 \mathrm{MHz}, \mathrm{MeOD}-d_{4}\right) \delta 8.19(\mathrm{~d}, J=16.2 \mathrm{~Hz}, 1 \mathrm{H}), 6.79$ $(\mathrm{d}, J=16.2 \mathrm{~Hz}, 1 \mathrm{H}), 6.20(\mathrm{~s}, 2 \mathrm{H}), 3.95(\mathrm{~s}, 6 \mathrm{H}), 3.86(\mathrm{~s}$, $3 \mathrm{H}) .{ }^{13} \mathrm{C}$ NMR (100 MHz, MeOD- $\left.d_{4}\right) \delta 171.3,162.4$, $162.3,137.4,115.7,104.9,92.5,55.9,51.7$. HRMS (ESI) cald for $\mathrm{C}_{12} \mathrm{H}_{15} \mathrm{O}_{5}[\mathrm{M}+\mathrm{H}]^{+} 239.0914$, found 239.0910.

Synthesis of compounds 6a-6e. A mixture of 5 (100 mg, $0.42 \mathrm{mmol}, 1 \mathrm{eq}), \mathrm{K}_{2} \mathrm{CO}_{3}(232.1 \mathrm{mg}$, $1.68 \mathrm{mmol}, 4 \mathrm{eq}$ ) and different alkynyl bromide $(1.47 \mathrm{mmol}, 3.5 \mathrm{eq})$ in $4 \mathrm{~mL}$ anhydrous DMF was heated to $40{ }^{\circ} \mathrm{C}$ for $4 \mathrm{~h}$. The reaction was quenched with $\mathrm{NaCl}$ and extracted with ethylacetate. The organic layer was dried over anhydrous $\mathrm{Na}_{2} \mathrm{SO}_{4}$ to give a crude oil, which was purified with silica gel column chromatography to provide white solid $\mathbf{6 a - 6 e}$ in yields of $67 \%-88 \%$.
Synthesis of compound 8a. A mixture of $6 \mathbf{a}(110 \mathrm{mg}$, $0.4 \mathrm{mmol}), \mathrm{LiOH} \cdot \mathrm{H}_{2} \mathrm{O}(336 \mathrm{mg}, 8 \mathrm{mmol}, 20 \mathrm{eq})$ and THF $-\mathrm{H}_{2} \mathrm{O}(1: 1)(4 \mathrm{~mL})$ was stirred at $40{ }^{\circ} \mathrm{C}$ for $12 \mathrm{~h}$. The $\mathrm{pH}$ of the mixture adjusted to $2-3$ with $2 \mathrm{~N} \mathrm{HCl}$. The resulting mixture was extracted with ethylacetate. The organic layer was dried over anhydrous $\mathrm{Na}_{2} \mathrm{SO}_{4}$ and concentrated under reduced pressure to give a crude oil. The mixture of the crude oil, $7(211 \mathrm{mg}, 0.8 \mathrm{mmol}$, 2 eq), EDCI ( $155 \mathrm{mg}, 0.8 \mathrm{mmol}, 2 \mathrm{eq}), \mathrm{DMAP}(1.2 \mathrm{mg}$, $0.01 \mathrm{mmol})$, and $\mathrm{Et}_{3} \mathrm{~N}(110.9 \mu \mathrm{L}, 0.8 \mathrm{mmol}, 2 \mathrm{eq})$ in $1 \mathrm{~mL} \mathrm{CH}_{2} \mathrm{Cl}_{2}$ was stirred at room temperature for $12 \mathrm{~h}$ and quenched with sat. $\mathrm{NaHCO}_{3}$. The resulting mixture was extracted with $\mathrm{CH}_{2} \mathrm{Cl}_{2}$. The $\mathrm{CH}_{2} \mathrm{Cl}_{2}$ layer was dried over anhydrous $\mathrm{Na}_{2} \mathrm{SO}_{4}$ to give a crude oil, which was purified by silica gel column chromatography to provide a white solid 8a (109 mg, $0.22 \mathrm{mmol}, 54 \%$ for two steps). ${ }^{1} \mathrm{H}$ NMR $\left(400 \mathrm{MHz}, \mathrm{CDCl}_{3}\right) \delta 8.10(\mathrm{~d}, J=16.2 \mathrm{~Hz}$, $1 \mathrm{H}), 6.71(\mathrm{~d}, J=16.2 \mathrm{~Hz}, 1 \mathrm{H}), 6.20(\mathrm{~d}, J=5.2 \mathrm{~Hz}, 3 \mathrm{H})$, $5.74(\mathrm{t}, J=8.1 \mathrm{~Hz}, 1 \mathrm{H}), 5.53(\mathrm{~d}, J=3.1 \mathrm{~Hz}, 1 \mathrm{H}), 4.73(\mathrm{q}$, $J=4.9 \mathrm{~Hz}, 3 \mathrm{H}), 4.60(\mathrm{~d}, J=12.4 \mathrm{~Hz}, 1 \mathrm{H}), 3.95-3.75(\mathrm{~m}$, $7 \mathrm{H}), 3.20-3.04(\mathrm{~m}, 1 \mathrm{H}), 2.94(\mathrm{~d}, J=9.4 \mathrm{~Hz}, 1 \mathrm{H}), 2.58(\mathrm{t}$, $J=2.3 \mathrm{~Hz}, 1 \mathrm{H}), 2.54-2.13(\mathrm{~m}, 6 \mathrm{H}), 1.65(\mathrm{dd}, J=19.5$, $6.7 \mathrm{~Hz}, 1 \mathrm{H}), 1.60-1.54(\mathrm{~m}, 3 \mathrm{H}), 1.14(\mathrm{t}, J=12.6 \mathrm{~Hz}, 1 \mathrm{H})$. 
${ }^{13} \mathrm{C}$ NMR $\left(100 \mathrm{MHz}, \mathrm{CDCl}_{3}\right) \delta 169.7,168.8,161.4,161.0$, $138.8,136.4,135.6,131.0,120.6,116.9,106.4,100.1,91.4$, 81.2, 78.0, 76.3, 67.1, 63.5, 60.1, 56.0, 55.9, 42.9, 36.8, 26.3, 25.3, 24.0. HRMS (ESI) cald for $\mathrm{C}_{29} \mathrm{H}_{32} \mathrm{NaO}_{8}[\mathrm{M}+\mathrm{Na}]^{+}$ 531.1989 , found 531.1992.

8b (white solid, 30\%) was synthesized following the similar procedure for 8a. ${ }^{1} \mathrm{H}$ NMR $\left(400 \mathrm{MHz} \mathrm{CDCl}_{3}\right) \delta$ $8.11(\mathrm{~d}, J=16.2 \mathrm{~Hz}, 1 \mathrm{H}), 6.70(\mathrm{~d}, J=16.2 \mathrm{~Hz}, 1 \mathrm{H}), 6.20$ $(\mathrm{d}, J=3.2 \mathrm{~Hz}, 1 \mathrm{H}), 6.12(\mathrm{~s}, 2 \mathrm{H}), 5.74(\mathrm{t}, J=8.1 \mathrm{~Hz}, 1 \mathrm{H})$, $5.53(\mathrm{~d}, J=2.8 \mathrm{~Hz}, 1 \mathrm{H}), 4.73(\mathrm{~d}, J=12.5 \mathrm{~Hz}, 1 \mathrm{H}), 4.60(\mathrm{~d}$, $J=12.3 \mathrm{~Hz}, 1 \mathrm{H}), 4.13(\mathrm{t}, J=7.0 \mathrm{~Hz}, 2 \mathrm{H}), 3.93-3.77(\mathrm{~m}$, $7 \mathrm{H}), 3.13(\mathrm{t}, J=9.6 \mathrm{~Hz}, 1 \mathrm{H}), 2.94(\mathrm{~d}, J=9.4 \mathrm{~Hz}, 1 \mathrm{H}), 2.77-$ $2.63(\mathrm{~m}, 2 \mathrm{H}), 2.55-2.13(\mathrm{~m}, 6 \mathrm{H}), 2.07$ (s, 1H), 1.70-1.63 (m, $1 \mathrm{H}), 1.25(\mathrm{~s}, 3 \mathrm{H}), 1.14(\mathrm{t}, J=12.5 \mathrm{~Hz}, 1 \mathrm{H}) .{ }^{13} \mathrm{C} \mathrm{NMR}$ $\left(100 \mathrm{MHz}, \mathrm{CDCl}_{3}\right) \delta 169.7,168.8,162.0,161.5,138.9$, 136.5, 135.7, 131.1, 131.0, 129.0, 120.5, 116.6, 91.1, 81.3, 70.3, 67.1, 66.2, 63.5, 60.1, 55.9, 43.0, 36.8, 26.4, 25.3, 24.1, 19.7, 18.2. HRMS (ESI) cald for $\mathrm{C}_{30} \mathrm{H}_{34} \mathrm{NaO}_{8}[\mathrm{M}+\mathrm{Na}]^{+}$ 545.2146, found 545.2148.

8c (white solid, 44\%) was synthesized following the similar procedure for 8a. ${ }^{1} \mathrm{H}$ NMR $\left(400 \mathrm{MHz} \mathrm{CDCl}_{3}\right) \delta$ $8.09(\mathrm{~d}, J=16.2 \mathrm{~Hz}, 1 \mathrm{H}), 6.68(\mathrm{~d}, J=16.2 \mathrm{~Hz}, 1 \mathrm{H}), 6.18$ $(\mathrm{s}, 1 \mathrm{H}), 6.10(\mathrm{~s}, 2 \mathrm{H}), 5.72(\mathrm{t}, J=8.0 \mathrm{~Hz}, 1 \mathrm{H}), 5.52(\mathrm{~s}, 1 \mathrm{H})$, $4.71(\mathrm{~d}, J=12.4 \mathrm{~Hz}, 1 \mathrm{H}), 4.59(\mathrm{~d}, J=12.4 \mathrm{~Hz}, 1 \mathrm{H}), 4.10(\mathrm{t}$, $J=5.9 \mathrm{~Hz}, 2 \mathrm{H}), 3.85(\mathrm{~s}, 7 \mathrm{H}), 3.10(\mathrm{t}, J=9.4 \mathrm{~Hz}, 1 \mathrm{H}), 2.92$ $(\mathrm{d}, J=9.4 \mathrm{~Hz}, 1 \mathrm{H}), 2.53-2.10(\mathrm{~m}, 8 \mathrm{H}), 2.01(\mathrm{dd}, J=12.0$, $5.4 \mathrm{~Hz}, 3 \mathrm{H}), 1.68-1.60(\mathrm{~m}, 1 \mathrm{H}), 1.54(\mathrm{~s}, 3 \mathrm{H}), 1.12(\mathrm{t}$, $J=12.8 \mathrm{~Hz}, 1 \mathrm{H}) .{ }^{13} \mathrm{C} \mathrm{NMR}\left(100 \mathrm{MHz}, \mathrm{CDCl}_{3}\right) \delta 169.6$, $168.8,162.5,161.5,138.8,136.5,135.6,130.8,120.4$, 116.3, 105.7, 91.0, 83.3, 81.2, 69.2, 67.0, 66.3, 63.4, 60.1, 55.8, 42.9, 36.8, 28.1, 26.3, 25.2, 24.0, 18.1, 15.2. HRMS (ESI) cald for $\mathrm{C}_{31} \mathrm{H}_{36} \mathrm{NaO}_{8}[\mathrm{M}+\mathrm{Na}]^{+}$559.2302, found 559.2305 .

8d (white solid, 64\%) was synthesized following the similar procedure for 8a. ${ }^{1} \mathrm{H}$ NMR $\left(400 \mathrm{MHz}, \mathrm{CDCl}_{3}\right)$ $\delta 8.10(\mathrm{~d}, J=16.2 \mathrm{~Hz}, 1 \mathrm{H}), 6.68(\mathrm{~d}, J=16.2 \mathrm{~Hz}, 1 \mathrm{H})$, $6.19(\mathrm{~d}, J=3.4 \mathrm{~Hz}, 1 \mathrm{H}), 6.09(\mathrm{~s}, 2 \mathrm{H}), 5.73(\mathrm{t}, J=8.1 \mathrm{~Hz}$, $1 \mathrm{H}), 5.52(\mathrm{~d}, J=3.0 \mathrm{~Hz}, 1 \mathrm{H}), 4.72(\mathrm{~d}, J=12.4 \mathrm{~Hz}, 1 \mathrm{H})$, $4.59(\mathrm{~d}, J=12.4 \mathrm{~Hz}, 1 \mathrm{H}), 4.02(\mathrm{t}, J=6.2 \mathrm{~Hz}, 2 \mathrm{H}), 3.86(\mathrm{~d}$, $J=13.4 \mathrm{~Hz}, 7 \mathrm{H}), 3.18-3.04(\mathrm{~m}, 1 \mathrm{H}), 2.93(\mathrm{~d}, J=9.4 \mathrm{~Hz}$, $1 \mathrm{H}), 2.55-2.12(\mathrm{~m}, 8 \mathrm{H}), 1.97(\mathrm{t}, J=2.3 \mathrm{~Hz}, 1 \mathrm{H}), 1.96-1.88$ $(\mathrm{m}, 2 \mathrm{H}), 1.72(\mathrm{dt}, J=14.7,7.4 \mathrm{~Hz}, 2 \mathrm{H}), 1.64(\mathrm{dd}, J=18.3$, $6.8 \mathrm{~Hz}, 1 \mathrm{H}), 1.55(\mathrm{~s}, 3 \mathrm{H}), 1.13(\mathrm{t}, J=12.7 \mathrm{~Hz}, 1 \mathrm{H}) .{ }^{13} \mathrm{C}$ NMR $\left(100 \mathrm{MHz}, \mathrm{CDCl}_{3}\right) \delta 169.7,168.8,162.6,161.5$, $138.9,136.6,135.7,130.9,120.5,116.3,105.6,91.0,84.0$, 81.2, 68.9, 67.6, 67.0, 63.5, 60.1, 55.9, 42.9, 36.8, 28.3, 26.3, 25.3, 25.1, 24.0, 18.3, 18.2. HRMS (ESI) cald $\mathrm{C}_{32} \mathrm{H}_{38} \mathrm{NaO}_{8}$ $[\mathrm{M}+\mathrm{Na}]^{+}$for 573.2459 , found 573.2462 .

8e (white solid, 42\%) was synthesized following the similar procedure for 8a. ${ }^{1} \mathrm{H} \mathrm{NMR}\left(400 \mathrm{MHz} \mathrm{CDCl}_{3}\right) \delta$ 8.11 (d, $J=16.1 \mathrm{~Hz}, 1 \mathrm{H}), 6.69$ (d, $J=16.2 \mathrm{~Hz}, 1 \mathrm{H}), 6.20$ $(\mathrm{s}, 1 \mathrm{H}), 6.09(\mathrm{~s}, 2 \mathrm{H}), 5.74(\mathrm{t}, J=7.8 \mathrm{~Hz}, 1 \mathrm{H}), 5.53(\mathrm{~s}$, $1 \mathrm{H}), 4.72(\mathrm{~d}, J=12.4 \mathrm{~Hz}, 1 \mathrm{H}), 4.60(\mathrm{~d}, J=12.5 \mathrm{~Hz}, 1 \mathrm{H})$, $4.00(\mathrm{t}, J=6.1 \mathrm{~Hz}, 2 \mathrm{H}), 3.87(\mathrm{~d}, J=13.5 \mathrm{~Hz}, 6 \mathrm{H}), 3.12(\mathrm{t}$, $J=9.3 \mathrm{~Hz}, 1 \mathrm{H}), 2.94(\mathrm{~d}, J=9.6 \mathrm{~Hz}, 1 \mathrm{H}), 2.50-2.12(\mathrm{~m}$, $8 \mathrm{H}), 1.96$ (s, 1H), 1.89-1.75 (m, 2H), $1.64(\mathrm{~m}, 6 \mathrm{H}), 1.55$ $(\mathrm{s}, 3 \mathrm{H}), 1.14(\mathrm{t}, J=12.4 \mathrm{~Hz}, 1 \mathrm{H}) .{ }^{13} \mathrm{C}$ NMR $(100 \mathrm{MHz}$, $\left.\mathrm{CDCl}_{3}\right) \delta 169.7,168.9,162.7,161.5,138.9,136.7,135.7$, $130.9,120.5,116.2,105.6,91.0,84.4,81.2,68.6,68.0,67.0$, 63.5, 60.1, 55.9, 42.9, 36.8, 28.8, 28.3, 26.3, 25.3, 25.3, 24.0, 18.5, 18.2. HRMS (ESI) cald for $\mathrm{C}_{33} \mathrm{H}_{40} \mathrm{NaO}_{8}[\mathrm{M}+\mathrm{Na}]^{+}$ 587.2615 , found 587.2618 .

\section{Synthesis of $10 a$}

A mixture of azide $(80 \mathrm{mg}, 0.097 \mathrm{mmol})$ and $8 \mathbf{a}(60 \mathrm{mg}$, $0.118 \mathrm{mmol}), \mathrm{CuSO}_{4}(0.014 \mathrm{mmol})$, sodium ascorbate $(0.014 \mathrm{mmol})$, tert-butanol $(1 \mathrm{~mL})$ and water $(0.5 \mathrm{~mL})$ was stirred overnight at room temperature. Then, $3 \mathrm{~mL}$ water was added and the reaction mixture was extracted $(3 \times 10 \mathrm{~mL})$ with EtOAc. The combined organic layers were washed with saturated brine, dried over anhydrous $\mathrm{Na}_{2} \mathrm{SO}_{4}$, and concentrated to give crude product, which was purified on a silica gel column to give compound 10a.

${ }^{1} \mathrm{H}$ NMR (400 MHz, MeOD) $\delta 8.15(\mathrm{~s}, 1 \mathrm{H}), 8.06(\mathrm{~d}$, $J=16.2 \mathrm{~Hz}, 1 \mathrm{H}), 7.77(\mathrm{~s}, 2 \mathrm{H}), 7.69(\mathrm{~s}, 1 \mathrm{H}), 7.51(\mathrm{~s}, 1 \mathrm{H})$, $7.26(\mathrm{~d}, J=9.3 \mathrm{~Hz}, 2 \mathrm{H}), 7.05(\mathrm{dd}, J=9.6,2.4 \mathrm{~Hz}, 2 \mathrm{H})$, 6.97-6.91 (m, 2H), $6.66(\mathrm{~d}, J=16.2 \mathrm{~Hz}, 1 \mathrm{H}), 6.33(\mathrm{~s}$, $2 \mathrm{H}), 5.70(\mathrm{t}, J=8.3 \mathrm{~Hz}, 1 \mathrm{H}), 5.59(\mathrm{~d}, J=3.2 \mathrm{~Hz}, 1 \mathrm{H})$, $5.24(\mathrm{~s}, 2 \mathrm{H}), 4.73-4.61(\mathrm{~m}, 2 \mathrm{H}), 4.62-4.57(\mathrm{~m}, 2 \mathrm{H})$, $3.85(\mathrm{~s}, 6 \mathrm{H}), 3.67(\mathrm{~m}, 10 \mathrm{H}), 3.62-3.56(\mathrm{~m}, 4 \mathrm{H}), 3.54(\mathrm{~d}$, $J=10.5 \mathrm{~Hz}, 7 \mathrm{H}), 3.46(\mathrm{t}, J=5.5 \mathrm{~Hz}, 4 \mathrm{H}), 3.34(\mathrm{~s}, 7 \mathrm{H}), 2.92$ (d, $J=9.5 \mathrm{~Hz}, 1 \mathrm{H}), 2.53(\mathrm{~s}, 2 \mathrm{H}), 2.41(\mathrm{~d}, J=6.9 \mathrm{~Hz}, 3 \mathrm{H})$, 2.37-2.25 (m, 2H), 2.23-2.08 (m, 3H), 1.55 (s, 4H), 1.29$1.28(\mathrm{~m}, 15 \mathrm{H})$.

\section{Synthesis of compound 12 in two methods}

Method A: A solution of $7(1.1 \mathrm{~g}, 4.16 \mathrm{mmol})$ in dimethylamine (20.8 mL, $41.6 \mathrm{mmol}, 2 \mathrm{~N}$ in THF) was stirred for $1 \mathrm{~h}$ at $0{ }^{\circ} \mathrm{C}$. The solvent was removed under reduced pressure. The residue was purified by silica gel column chromatography $\left(\mathrm{CH}_{2} \mathrm{Cl}_{2}: \mathrm{MeOH}=50: 1\right)$ to afford the desired product $11(1.2 \mathrm{~g}, 93 \%)$ as a white solid. ${ }^{1} \mathrm{H}$ NMR $\left(400 \mathrm{MHz}, \mathrm{CDCl}_{3}\right) \delta 5.58(\mathrm{t}, J=7.9 \mathrm{~Hz}, 1 \mathrm{H}), 4.10(\mathrm{dd}$, $J=30.7,13.1 \mathrm{~Hz}, 2 \mathrm{H}), 3.85(\mathrm{t}, J=9.2 \mathrm{~Hz}, 1 \mathrm{H}), 3.38(\mathrm{~s}, 1 \mathrm{H})$, $2.81(\mathrm{~d}, J=9.4 \mathrm{~Hz}, 1 \mathrm{H}), 2.73(\mathrm{dd}, J=12.9,5.1 \mathrm{~Hz}, 1 \mathrm{H})$, 2.61 (dd, $J=12.9,5.4 \mathrm{~Hz}, 1 \mathrm{H}), 2.51-2.38(\mathrm{~m}, 4 \mathrm{H}), 2.30$ $2.18(\mathrm{~m}, 8 \mathrm{H}), 2.17-2.06(\mathrm{~m}, 2 \mathrm{H}), 1.67-1.55(\mathrm{~m}, 1 \mathrm{H}), 1.52$ (s, 3H), 1.12-1.02 (m, 1H). ${ }^{13} \mathrm{C}$ NMR $\left(100 \mathrm{MHz}, \mathrm{CDCl}_{3}\right)$ $\delta$ 177.0, 141.2, 127.5, 81.7, 66.3, 64.2, 60.0, 57.6, 45.8, 44.3, 42.1, 37.2, 27.7, 26.0, 23.9, 18.1. HRMS (ESI) calcd for $\mathrm{C}_{17} \mathrm{H}_{28} \mathrm{~N}_{2} \mathrm{O}_{4}[\mathrm{M}+\mathrm{H}]^{+} 310.2013$, found 310.2015.

To a solution of 2,6-dimethoxylcinnamic acid (712 mg, $3.42 \mathrm{mmol}$ ), compound 11 (705 $\mathrm{mg}, 2.28 \mathrm{mmol})$, EDCI (655.6 mg, $3.42 \mathrm{mmol}$ ) and DMAP (27.8 mg, $0.228 \mathrm{mmol})$ in $25 \mathrm{~mL} \mathrm{CH}_{2} \mathrm{Cl}_{2}$ was added TEA $(0.45 \mathrm{~mL}, 3.42 \mathrm{mmol})$ 
at $0{ }^{\circ} \mathrm{C}$. The mixture was stirred for $8 \mathrm{~h}$ at room temperature. The reaction was quenched with saturated aqueous $\mathrm{NaHCO}_{3}$ and extracted with $\mathrm{CH}_{2} \mathrm{Cl}_{2}(3 \times 75 \mathrm{~mL})$. The combined organic layers were washed with saturated brine, dried over $\mathrm{Na}_{2} \mathrm{SO}_{4}$, and concentrated to give an oily crude product, which was purified on a silica gel column [DCM:MeOH =50:1] to yield compound 12 (987.2 $\mathrm{mg}, 86 \%)$ as a white solid. ${ }^{1} \mathrm{H}$ NMR $(400 \mathrm{MHz}$, $\left.\mathrm{CDCl}_{3}\right) \delta 8.16(\mathrm{~d}, J=16.3 \mathrm{~Hz}, 1 \mathrm{H}), 7.28(\mathrm{~d}, J=8.7 \mathrm{~Hz}$, $1 \mathrm{H}), 6.89(\mathrm{~d}, J=16.3 \mathrm{~Hz}, 1 \mathrm{H}), 6.56(\mathrm{~d}, J=8.4 \mathrm{~Hz}, 2 \mathrm{H})$, $5.67(\mathrm{t}, J=7.8 \mathrm{~Hz}, 1 \mathrm{H}), 4.84(\mathrm{~d}, J=12.8 \mathrm{~Hz}, 1 \mathrm{H}), 4.66(\mathrm{~d}$, $J=12.8 \mathrm{~Hz}, 1 \mathrm{H}), 3.97-3.80(\mathrm{~m}, 7 \mathrm{H}), 2.84(\mathrm{~d}, J=9.3 \mathrm{~Hz}$, $1 \mathrm{H}), 2.73(\mathrm{~d}, J=4.3 \mathrm{~Hz}, 1 \mathrm{H}), 2.65(\mathrm{~d}, J=5.9 \mathrm{~Hz}, 1 \mathrm{H})$, $2.58-2.26(\mathrm{~m}, 6 \mathrm{H}), 2.23(\mathrm{~s}, 6 \mathrm{H}), 2.15(\mathrm{~d}, J=12.5 \mathrm{~Hz}, 2 \mathrm{H})$, $1.58(\mathrm{~d}, J=20.6 \mathrm{~Hz}, 4 \mathrm{H}), 1.10$ (t, $J=12.8 \mathrm{~Hz}, 1 \mathrm{H}) .{ }^{13} \mathrm{C}$ NMR $\left(100 \mathrm{MHz}, \mathrm{CDCl}_{3}\right) \delta 177.2,168.3,160.2,136.3$, 136.1, 131.6, 128.5, 120.2, 112.2, 103.8, 81.3, 66.2, 64.0, 60.0, 58.5, 55.9, 45.9, 44.7, 43.3, 37.1, 27.2, 25.0, 23.9, 18.1. HRMS (ESI) calcd for $\mathrm{C}_{28} \mathrm{H}_{38} \mathrm{NO}_{7}[\mathrm{M}+\mathrm{H}]^{+} 500.2643$, found 500.2644 .

Method B. Synthesis of compound 2. To a mixture of 7 (53 $\mathrm{mg}, 0.2 \mathrm{mmol})$, EDCI $(115 \mathrm{mg}, 0.6 \mathrm{mmol})$, DMAP (1.2 $\mathrm{mg}, 0.01 \mathrm{mmol}$ ) and 2,6-dimethoxylcinnamic acid $(0.3 \mathrm{mmol}, 1.5 \mathrm{eq})$ in $\mathrm{CH}_{2} \mathrm{Cl}_{2} 2 \mathrm{~mL}$ was added triethylamine $(83.4 \mu \mathrm{L}, 0.6 \mathrm{mmol})$. After $12 \mathrm{~h}$, saturated $\mathrm{NaHCO}_{3}$ was added. The resulting mixture was extracted with $\mathrm{CH}_{2} \mathrm{Cl}_{2}$. The $\mathrm{CH}_{2} \mathrm{Cl}_{2}$ layer was dried over anhydrous $\mathrm{Na}_{2} \mathrm{SO}_{4}$, and concentrated under reduced pressure to give crude product, which was purified by silica gel column chromatography to afford compound $\mathbf{2}$ (yield 83\%). ${ }^{1} \mathrm{H}$ NMR $\left(400 \mathrm{MHz}, \mathrm{CDCl}_{3}\right) \delta 8.16(\mathrm{~d}, J=16.3 \mathrm{~Hz}$, $1 \mathrm{H}, \mathrm{H}-18), 7.30-7.22\left(\mathrm{~m}, 1 \mathrm{H}\right.$, overlap with $\mathrm{CHCl}_{3}$, $\left.\mathrm{H}-4^{\prime}\right), 6.83(\mathrm{~d}, J=16.3 \mathrm{~Hz}, 1 \mathrm{H}, \mathrm{H}-17), 6.54(\mathrm{~d}, J=8.4 \mathrm{~Hz}$, $\left.2 \mathrm{H}, \mathrm{H}-3^{\prime}, \mathrm{H}-5^{\prime}\right), 6.19$ (d, J=3.5 Hz, 1H, H-13), 5.73 (t, $J=8.1 \mathrm{~Hz}, 1 \mathrm{H}, \mathrm{H}-1), 5.53$ (d, $J=3.2 \mathrm{~Hz}, 1 \mathrm{H}, \mathrm{H}-13)$, $4.74(\mathrm{~d}, J=12.4 \mathrm{~Hz}, 1 \mathrm{H}, \mathrm{H}-14), 4.60(\mathrm{~d}, J=12.4 \mathrm{~Hz}, 1 \mathrm{H}$, $\mathrm{H}-14$ ), 3.96-3.75 (m, 7H, H-6, H-19, H-18), 3.14-3.02 (m, 1H, H-7), 2.91 (d, J=9.4 Hz, 1H, H-5), 2.49-2.11 (m, $6 \mathrm{H}, \mathrm{H}-2, \mathrm{H}-3, \mathrm{H}-8, \mathrm{H}-9), 1.71-1.60$ (m, 1H, H-8), 1.54 (s, 3H, H-15), 1.12 (t, $J=12.6 \mathrm{~Hz}, 1 \mathrm{H}, \mathrm{H}-3) .{ }^{13} \mathrm{C}$ NMR $\left(100 \mathrm{MHz}, \mathrm{CDCl}_{3}\right) \delta 169.6(\mathrm{C}-12), 168.4(\mathrm{C}-16), 160.2(\mathrm{C}-$ $\left.2^{\prime}, \mathrm{C}^{\prime} 6^{\prime}\right), 138.8(\mathrm{C}-11), 136.5(\mathrm{C}-18), 135.5(\mathrm{C}-10), 131.7(\mathrm{C}-$ $\left.4^{\prime}\right)$, 130.9(C-1), 120.5(C-13), 119.5(C-17), 111.9(C-1'), 103.7(C-3', 5'), 81.2(C-6), 67.1(C-14), 63.4(C-5), 60.1(C4), 55.9(C-19, C-20), 42.8(C-7), 36.7(C-3), 26.2(C-8), 25.1(C-9), 24.0(C-2), 18.1(C-15). HRMS (ESI) cald for $\mathrm{C}_{26} \mathrm{H}_{34} \mathrm{NO}_{7}\left[\mathrm{M}+\mathrm{NH}_{4}\right]^{+}$472.2330, found 472.2329.

A solution of compound $2(930 \mathrm{mg}, 2.05 \mathrm{mmol})$ and dimethylamine $\left(10.5 \mathrm{~mL}, 21.0 \mathrm{mmol}, 2 \mathrm{~N}\right.$ in THF) at $0{ }^{\circ} \mathrm{C}$ was stirred $1 \mathrm{~h}$ at $0{ }^{\circ} \mathrm{C}$. The solvent was removed under reduced pressure. The residue was purified by silica gel column chromatography $\left(\mathrm{CH}_{2} \mathrm{Cl}_{2}: \mathrm{MeOH}=50: 1\right)$ to afford the desired product $12(985 \mathrm{mg}, 96 \%)$ as a white solid.

Synthesis of compound 13. To a solution of compound $12(1.15 \mathrm{~g}, 2.3 \mathrm{mmol})$ in methanol $(23 \mathrm{~mL})$, fumaric acid (267 mg, $2.3 \mathrm{mmol}$ ) was added. The mixture was stirred for $6.5 \mathrm{~h}$ and concentrated under vacuum to afford compound $\mathbf{1 3}$ as a white amorphous solid (1.3 g, yield 92\%). ${ }^{1} \mathrm{H}$ NMR (400 MHz, DMSO-d6) $\delta 12.95$ (s, $2 \mathrm{H}), 8.00(\mathrm{~d}, J=16.3 \mathrm{~Hz}, 1 \mathrm{H}), 7.37(\mathrm{t}, J=8.4 \mathrm{~Hz}, 1 \mathrm{H})$, $6.78(\mathrm{~d}, J=16.3 \mathrm{~Hz}, 1 \mathrm{H}), 6.72(\mathrm{~d}, J=8.4 \mathrm{~Hz}, 2 \mathrm{H}), 6.61(\mathrm{~s}$, $2 \mathrm{H}), 5.59(\mathrm{t}, J=7.6 \mathrm{~Hz}, 1 \mathrm{H}), 4.79(\mathrm{~d}, J=12.7 \mathrm{~Hz}, 1 \mathrm{H}), 4.57$ $(\mathrm{d}, J=12.6 \mathrm{~Hz}, 1 \mathrm{H}), 4.03(\mathrm{t}, J=9.5 \mathrm{~Hz}, 1 \mathrm{H}), 3.86(\mathrm{~s}, 6 \mathrm{H})$, 2.77-2.54 (m, 4H), 2.39-2.23 (m, 4H), 2.18 (s, 6H), 2.10 (dd, $J=24.6,10.8 \mathrm{~Hz}, 3 \mathrm{H}), 1.65$ (t, $J=11.4 \mathrm{~Hz}, 1 \mathrm{H}), 1.48$ $(\mathrm{s}, 3 \mathrm{H}), 0.94(\mathrm{t}, J=12.3 \mathrm{~Hz}, 1 \mathrm{H}) .{ }^{13} \mathrm{C}$ NMR $(100 \mathrm{MHz}$, DMSO-d6) $\delta 177.1,167.2,166.2,159.6,135.8,135.2$, 134.2, 132.2, 128.1, 119.4, 110.7, 104.1, 80.4, 66.0, 63.2, 59.8, 57.9, 56.0, 45.2, 43.3, 42.6, 36.6, 25.6, 24.2, 23.1, 17.5. HRMS (ESI) calcd for $\mathrm{C}_{28} \mathrm{H}_{38} \mathrm{NO}_{7}[\mathrm{M}+\mathrm{H}]^{+} 500.2643$, found 500.2645 .

\section{Cell culture}

Human triple negative breast cancer cell lines MDAMB-231, SUM159, BT574, and mouse breast cancer cell 4T1 were purchased from ATCC and were cultured in 1640 medium supplement with 10\% FBS under a 5\% $\mathrm{CO}_{2}$ humidified atmosphere at $37^{\circ} \mathrm{C}$. Hs578T and MDAMB-468 breast cancer cells were cultured in DMEM medium supplement with $10 \%$ FBS under a $5 \% \mathrm{CO}_{2}$ humidified atmosphere at $37^{\circ} \mathrm{C}$.

\section{MTT assay}

Human triple negative breast cancer cells were seeded into 96 well plate at the density of 4000 cells/200 $\mu \mathrm{L} /$ well. After the adherent cell growth, DMOCPTL was added with a series concentration for $72 \mathrm{~h}$. Then, $20 \mu \mathrm{L}$ thiazolyl blue tetrazolium bromide (MTT, $5 \mathrm{mg} / \mathrm{mL}$ ) was added and incubated for additional $4-6 \mathrm{~h}$. The supernatant was discarded and the precipitate was dissolved with DMSO. Then, the absorbance at $570 \mathrm{~nm}$ was measured.

\section{Cell colony formation assay}

Breast cancer cells MDA-MB-231 and 4T1 were seeded into 6 well plate with a concentration of 500 cells/ $1 \mathrm{~mL} /$ well. After 8-12 h, compounds at different concentration were added and incubated for 10 days. Then, the cells were fixed with $4 \%$ polyoxymethylene at room temperature for $15 \mathrm{~min}$. After being washed with PBS, the cells were stained with crystal violet solution at room temperature for $15 \mathrm{~min}$. The excess crystal violet was removed and washed with water for 3 times. The number of colonies was counted. 


\section{Cell death manner assay}

To investigate the mechanism of DMOCPTL in breast cancer proliferation inhibition, the manners of cells death were analyzed. The cell apoptosis inhibitor Z-VAD-FMK, cell autophagy inhibitor 3-methyladenine, cell necrosis inhibitor necrostatin-1, and ferroptosis inhibitors $N$-Acetyl-L-cysteine, deferoxamine and Ferrostatin-1 were purchased and stored at $-20{ }^{\circ} \mathrm{C}$. MDA-MB-231 cells were seeded with a density of at 5000 cells $/ 200 \mu \mathrm{L} /$ well into 96 well plate. After $8-12 \mathrm{~h}$, DMOCPTL was added at different concentrations. Following that $10 \mu \mathrm{M}$ Z-VAD-FMK, $5 \mathrm{mM}$ 3-methyladenine, $10 \mu \mathrm{M}$ necrostatin-1, $3 \mathrm{mM} \mathrm{N}$-acetyl-L-cysteine, $200 \mu \mathrm{M}$ deferoxamine and $10 \mu \mathrm{M}$ Ferrostatin-1 were added and co-incubated with DMOCPTL, respectively, for $72 \mathrm{~h}$. Then, $20 \mu \mathrm{L}$ thiazolyl blue tetrazolium bromide (MTT, $5 \mathrm{mg} / \mathrm{mL}$ ) was added and incubated at $37{ }^{\circ} \mathrm{C}$ for additional $4 \mathrm{~h}$. Then, supernatant was discarded and $200 \mu \mathrm{L}$ DMSO was added to dissolve the precipitate. After $15 \mathrm{~min}$, the absorbance was measured at $570 \mathrm{~nm}$. The percentage of inhibition was calculated.

\section{Cell apoptosis assay}

MDA-MB-231 and SUM159 cells were collected and washed with cold PBS. Then, the cells were suspended with $100 \mu \mathrm{L}$ of binding buffer; $5 \mu \mathrm{L}$ of Annexin V-APC and $5 \mu \mathrm{L}$ PI were added and incubated for $15 \mathrm{~min}$ in dark at room temperature. Then, the cells were analyzed by flow cytometry within $1 \mathrm{~h}$.

\section{Flow cytometry with reactive $\mathrm{O}_{2}$ species assay}

MDA-MB-231 and SUM159 cells in logarithmic growth period were digested and divided into control group, DMOCPTL-treated group. The cells were washed with PBS for 3 times and DMOCPTL was added. Then, $10 \mu$ M DCF-DA or BODIPY 581/591 C11 were added and co-incubated with DMOCPTL in an incubator at $37{ }^{\circ} \mathrm{C}$. The cells were collected by centrifugation and analyzed by flow cytometry within $1 \mathrm{~h}$.

\section{$\mathrm{Fe}^{2+}$ intensity assay}

MDA-MB-231 was collected and washed with cold PBS buffer. Then, cells were incubated with PGSK at $10 \mu \mathrm{M}$ at $37{ }^{\circ} \mathrm{C}$ for $30 \mathrm{~min}$ in dark. Then, cells were collected, washed and analyzed by flow cytometry within $1 \mathrm{~h}$.

\section{RNA interference}

Breast cancer cell at about $40-50 \%$ confluence was transfected with siRNA using lipofectamine ${ }^{\mathrm{TM}} 2000$ according to the manufacturer's instructions. After
$48 \mathrm{~h}$, the efficacy of siRNA was confirmed by western blot assay.

\section{Immunofluorescence assay}

MDA-MB-231 cells were cultured on gelatin-coated glass coverslips for $24 \mathrm{~h}$ and treated with DMOCPTL for $48 \mathrm{~h}$. Then, the cells were fixed in $4 \%$ paraformaldehyde for $20 \mathrm{~min}$ and permeabilized with Triton X-100 for $15 \mathrm{~min}$. After blocked with horse serum for $30 \mathrm{~min}$, the cells were incubated with GPX4 antibody over night at $4{ }^{\circ} \mathrm{C}$. After the incubation, the cells were washed five times with PBST and incubated with the anti-rabbit IgG-FITC secondary antibody for $1 \mathrm{~h}$ at room temperature. Then, the cell nucleus was stained with DAPI and analyzed using fluorescence microscopy. As to flow cytometry assay, MDA-MB-231 cells with DMOCPTL treatment for $48 \mathrm{~h}$ were collected, fixed with $4 \%$ paraformaldehyde for $20 \mathrm{~min}$, permeabilized with Triton X-100 for $15 \mathrm{~min}$, incubated with GPX4 antibody overnight, then incubated with corresponding FITC-conjunct second antibody. Fluorescence intensity of GPX4 expression was analyzed by flow cytometry.

\section{Western blot assay}

MDA-MB-231 and SUM159 cells were collected and lysed with RIPA buffer for $30 \mathrm{~min}$ on ice. Then, the protein $(50 \mu \mathrm{g})$ from each sample were separated by $12 \%$ tris-acrylamide gel electrophoresis and transferred onto PVDF membrane. After blocking with 5\% skim milk for $1 \mathrm{~h}$ at room temperature, Primary antibodies against GPX-4, EGR1, Bax, Bcl-2, Bcl-xl, cytochrome C, caspase 3 , caspase 9 and PARP was used and incubated at $4{ }^{\circ} \mathrm{C}$ overnight on rotary shaker. After washing with PBST for 5 times, the membrane was probed with goat anti-rabbit IgG highly cross-adsorbed secondary antibody $(1: 10,000)$ for $2 \mathrm{~h}$ at room temperature. Then, the membrane was washed for 5 times and developed with ECL reagent.

\section{Probe pull-down assay}

The pull-down experiments were performed using the probe of DMOCPTL. In vitro pull-down assay, MDAMB-231 and SUM159 cells were collected and lysed, respectively, in RIPA buffer supplemented with protease inhibitors. Then, probe $\mathbf{1 0}$ was added and incubated for $2 \mathrm{~h}$ at room temperature with different concentrations. Then, excessive pre-cooled methanol was added and incubated at $-80^{\circ} \mathrm{C}$ for $30 \mathrm{~min}$ to precipitate the protein. After centrifuged at $14,000 \times g$ for $15 \mathrm{~min}$, the precipitated proteins were dissolved and incubated with streptavidin conjunct agarose $\mathrm{A}+\mathrm{G}$ beads at $4{ }^{\circ} \mathrm{C}$ overnight. Then, the streptavidin beads were washed three times with PBS buffer, and the bead-bound proteins were collected and detected by western blot experiments. 
As to in situ pull-down assay, MDA-MB-231 and SUM159 cells were seeded into 6 well plate. After $12 \mathrm{~h}$, probe $8 \mathbf{a}$ was added at different concentrations and incubated for additional $6 \mathrm{~h}$. Then, the cells were collected and lysed, respectively, in RIPA buffer supplemented with protease inhibitors. After the centrifugation, the supernatant was collected and a mix of TBTA $(0.1 \mathrm{mM})$, TCEP $(1 \mathrm{mM})$, biotin- $\mathrm{N}_{3}(100 \mu \mathrm{M})$ and $\mathrm{CuSO}_{4}(1 \mathrm{mM})$ was added to conjunct biotin on probe $8 \mathbf{a}$. Then, excessive pre-cooled methanol was added and incubated at $-80^{\circ} \mathrm{C}$ for $30 \mathrm{~min}$ to precipitate the protein. After centrifuged at $14,000 \times g$ for $15 \mathrm{~min}$, the precipitated proteins were dissolved and incubated with streptavidin conjunct agarose $\mathrm{A}+\mathrm{G}$ beads at $4{ }^{\circ} \mathrm{C}$ overnight. Then, the streptavidin beads were washed three times with PBS buffer, and the bead-bound proteins were collected and detected by western blot experiments or sliver staining.

\section{Co-localization assay}

MDA-MB-231 cells were cultured on gelatin-coated glass coverslips for $24 \mathrm{~h}$ and treated with probe 10a for $6 \mathrm{~h}$ at $2 \mu \mathrm{M}$. The cells were fixed in $4 \%$ paraformaldehyde for $20 \mathrm{~min}$ and permeabilized with Triton X-100 for $15 \mathrm{~min}$. After being blocked with horse serum for $30 \mathrm{~min}$, the cells were incubated with anti-GPX4 antibody (rabbit) and anti-Ubiquitin (mouse) over night at $4{ }^{\circ} \mathrm{C}$. After the incubation, the cells were washed five times with PBST and incubated with the anti-rabbit IgG-FITC secondary antibody and anti-mouse IgG-AF647 secondary antibody for $2 \mathrm{~h}$ at room temperature. After being washed for 3 times, the cell nucleus was stained with DAPI and analyzed using fluorescence microscopy.

\section{Bioinformatics analysis}

The relationship between GPX4 and gene functional states was analyzed by CancerSEA (http://biocc.hrbmu .edu.cn/CancerSEA/). The expression level of EGR1 in normal breast tissue and breast cancer tissues with different stages was analyzed in TCGA by UALCAN analysis (http://ualcan.path.uab.edu). The immunohistochemical staining intensity of EGR1 in normal breast tissue and breast cancer tissues with different stages were analyzed by Human Protein Atlas database (http://www.proteinatl as.org/).

\section{Docking simulations}

Molecular Docking simulations were performed with the software of AutoDock. The crystal structure of the published GPX4 (PDB code: 5H5S) was retrieved from the RCSB Protein Data Bank. The solvent molecules within the protein structure were removed in the docking calculations, and the best ligand pose was chosen according to the dock score.

\section{In vitro ubiquitination assay}

MDA-MB-231 cells in logarithmic growth period were plated into 6 -well plate with the density at $1 \times 10^{5}$ cells/ $\mathrm{mL} /$ well. Then, DMOCPTL at the concentration of $0.05 \mu \mathrm{M}, 0.1 \mu \mathrm{M}, 0.2 \mu \mathrm{M}, 0.5 \mu \mathrm{M}$ and $1 \mu \mathrm{M}$ were added and incubated for $24 \mathrm{~h}$. Then, $10 \mu \mathrm{M}$ MG-132 was added to inhibit the protein degradation for $4 \mathrm{~h}$. After that the cells were collected by centrifugation and washed with PBS, subsequently suspended with RIPA buffer for 30 min on ice. After centrifugation, the GPX4 antibody was added with 1:100 dilution for $2 \mathrm{~h}$ on ice, then 10 $\mu \mathrm{L}$ agarose $\mathrm{G}$ was added and co-incubated at $4{ }^{\circ} \mathrm{C}$ overnight on rotary shaker. The samples were collected and washed with PBS for 3 times, then the SDS-PAGE protein electrophoresis was performed and the protein was transferred onto PVDF membrane. Following that the membrane was blocked in 5\% skim milk for $1 \mathrm{~h}$ at room temperature, and subsequently was incubated with ubiquitin antibody (P4D1) at $4{ }^{\circ} \mathrm{C}$ overnight on rotary shaker.

\section{Immuno-coprecipitation assay}

MDA-MB-231 and SUM159 cells were collected and lysed with RIPA buffer for $30 \mathrm{~min}$ on ice. The indicated protein in the cell lysates was immunoprecipitated using ubiquitin antibody. After incubated with ubiquitin antibody at $4{ }^{\circ} \mathrm{C}$ for $6 \mathrm{~h}, 10 \mu \mathrm{L}$ agarose $\mathrm{A}+\mathrm{G}$ was added and co-incubated at $4{ }^{\circ} \mathrm{C}$ overnight on rotary shaker. The samples were washed with PBS and visualized using an ECL detection system.

\section{Pharmacodynamics}

Compound 13 was injected into three male SD rats by intravenous administration at a dose of $1 \mathrm{mg} / \mathrm{kg}$. Then, the blood samples from jugular sinus of rats were collected at $2 \mathrm{~min}, 5 \mathrm{~min}, 15 \mathrm{~min}, 30 \mathrm{~min}, 1 \mathrm{~h}, 2 \mathrm{~h}, 3 \mathrm{~h}$, $4 \mathrm{~h}, 6 \mathrm{~h}$ and $8 \mathrm{~h}$ after administration. After being centrifugated at $12000 \mathrm{rpm}$ for $1 \mathrm{~min}$, the supernatant was collected, respectively. Then, equal amount of acetonitrile was added into the sample, which was vortexed for $2 \mathrm{~min}$, centrifugated at $12000 \mathrm{rpm}$ for $5 \mathrm{~min}$, and then the supernatant was collected and analyzed by LC/MS. The pharmacodynamic of $\mathbf{1 3}$ on SD rats was calculated by DAS 3.3.

\section{Acute toxicity assay in Bar b/c mice}

To verify the toxicity of $\mathbf{1 3}$, Bar b/c mice were administrated by intravenous administration at a dose of $50 \mathrm{mg} /$ $\mathrm{kg}$ or oral administration with $\mathbf{1 3}$ at a dose of $500 \mathrm{mg} / \mathrm{kg}$ or vehicle control. During the experiment, their behavior was observed, and the body weight was recorded every day. The level of GPT, GOT and $\mathrm{Cr}$ in serum was detected by ELISA assay and the major organs of mice including liver, spleen, lung, kidney, heart, and brain were 
weighted, fixed with $4 \%$ paraformaldehyde and sectioned to $4 \mu \mathrm{m}$ slides. After dewaxing and hydration, HE staining was performed. The histology and morphology were observed under microscope.

\section{In vivo anti-tumor activity assay}

The experimental procedures of the animal experiments were permitted by the Animal Care and Use Committee at Nankai University. 4T1 triple negative breast cancer cells $\left(1 \times 10^{5}\right)$ were injected on the Bar b/c mouse's breast fat pad. Then, compound $\mathbf{1 3}$ was administrated through intravenous injection $(7.5 \mathrm{mg} / \mathrm{kg})$ according to body weight. Body weights and tumor size were measured every other day. The tumor growth inhibition was calculated and the tumor weight was recorded when the mice were sacrificed. The tumor was collected and crushed with cell lysate buffer. Then, the expression of GPX4 and EGR1 were analyzed in vehicle and 13-treated group by western blot assay. Furthermore, to analysis the effect of 13 on the overall survival compound 13 was administrated orally $(50 \mathrm{mg} / \mathrm{kg}$ ) according to body weight on tumor animal model. After administration for 6 times every other day the overall survival and body weight were recorded and analyzed.

\section{Immunohistochemical assay}

The tumors isolated from the mice were fixed with $4 \%$ paraformaldehyde and sectioned to $4 \mu \mathrm{m}$ slides. As to IHC assay, after dewaxing, hydration and antigen retrieval, the slides were incubated with primary antibodies at $4{ }^{\circ} \mathrm{C}$ overnight. After washed with PBST for 3 times, the slides were incubated with biotinylated secondary antibody for $1 \mathrm{~h}$. Then, the slides were developed by DAB.

\section{Results \\ DMOCPTL inhibited the antiproliferation of TNBC cells}

Sesquiterpene lactone PTL showed moderate activity against breast cancer [30]. To improve the anticancer effect of parthenolide, we designed and synthesized a series of parthenolide derivatives. Ultimately, we identified that DMOCPTL exhibited the most potent antiTNBC activity [31]. As shown in Fig. 2b, DMOCPTL significantly inhibited proliferation of MDA-MB-231 and SUM159 cells in a dose dependent manner. To further investigate the inhibitory effect of DMOCPTL on proliferation of TNBC cells, the colony formation of MDA-MB-231 and 4T1 cells assay was performed. After treatment of DMOCPTL for 10 days, the number of colonies was counted. The number of colonies was $82.7 \pm 5.5$, $68 \pm 1,60 \pm 3$ and 0 with treatment of DMOCPTL at different concentrations of $0,0.05,0.1$ and $0.25 \mu \mathrm{M}$, respectively, in human breast cancer MDA-MB-231 cells. As to mouse breast cancer $4 \mathrm{~T} 1$ cells, the number of colonies was $44 \pm 1,36.7 \pm 2.5,33.3 \pm 1.5$ and 0 with the treatment of DMOCPTL at 0, 0.05, 0.1 and $0.25 \mu \mathrm{M}$, respectively. Moreover, we compared the efficacy of DMOCPTL and PTL on inhibiting colony formation of MDA-MB-231 cells. As shown in Fig. 2d, the number of colonies was $82.7 \pm 5.5,71.5 \pm 1.5$ and 0 after treatment with vehicle, PTL or DMOCPTL at the same concentration of $0.5 \mu \mathrm{M}$. These results indicated that DMOCPTL could significantly inhibit colony formation of TNBC cells. Moreover, the inhibitory effect of DMOCPTL was evidently higher than that of PTL.

\section{DMOCPTL induced apoptosis and ferroptosis of TNBC cells}

To reveal the mechanism of DMOCPTL, the death manners were analyzed. In this experiment, the apoptosis inhibitor Z-VAD-FMK, cell autophagy inhibitor 3-methyladenine, cell necrosis inhibitor necrostatin-1, and ferroptosis inhibitors $\mathrm{N}$-acetyl-L-cysteine, deferoxamine and Ferrostatin-1 were used. As shown in Fig. 3, there was no significant change in the percentage of cell viability after the combination of DMOCPTL and cell necrosis inhibitor necrostatin-1, which indicated that DMOCPTL could not induce cell necrosis (Fig. 3a). Meanwhile, the percentage of cell viability was not affected clearly after the combination of DMOCPTL and cell autophagy inhibitor 3-methyladenine, which suggested that DMOCPTL could not induce cell autophagy (Fig. 3b). We then investigated whether the effect of DMOCPTL was achieved by inducing cell apoptosis. The apoptosis inhibitor Z-VAD-FMK was combined with DMOCPTL for treatment of MDA-MB-231 cells for $48 \mathrm{~h}$. The effect of DMOCPTL was inhibited by cell apoptosis inhibitor Z-VAD-FMK, which prompted us to infer that the effect of DMOCPTL may be through inducing cell apoptosis (Fig. 3c). As cell apoptosis inhibitor could not completely inhibit the effect of DMOCPTL, we further analyzed whether DMOCPTL could induce ferroptosis. The effect of DMOCPTL was inhibited by cell ferroptosis inhibitors $\mathrm{N}$-Acetyl-L-cysteine, deferoxamine and Ferrostatin-1 which demonstrated that the effect of DMOCPTL was achieved partly by inducing cell ferroptosis (Fig. 3d-f). These results suggested that the effect of DMOCPTL may be achieved by inducing apoptosis and ferroptosis of TNBC cells.

In order to investigate the effect of DMOCPTL on cell apoptosis, the cell apoptosis assay was performed by Annexin V/PI staining. The percentage of apoptosis cells was the sum of early apoptosis (Annexin $\mathrm{V}+/ \mathrm{PI}-$ ) and late apoptosis (Annexin $\mathrm{V}+/ \mathrm{PI}+$ ). As shown in Fig. 4b, the percentage of cell apoptosis was $3.60 \pm 1.53, \quad 4.27 \pm 1.22, \quad 12.60 \pm 1.95$ and $75.60 \pm 1.30$ after the treatment of DMOCPTL at the concentration of $0,0.2 \mu \mathrm{M}, 0.5 \mu \mathrm{M}$ and $1 \mu \mathrm{M}$, respectively.Furthermore, 

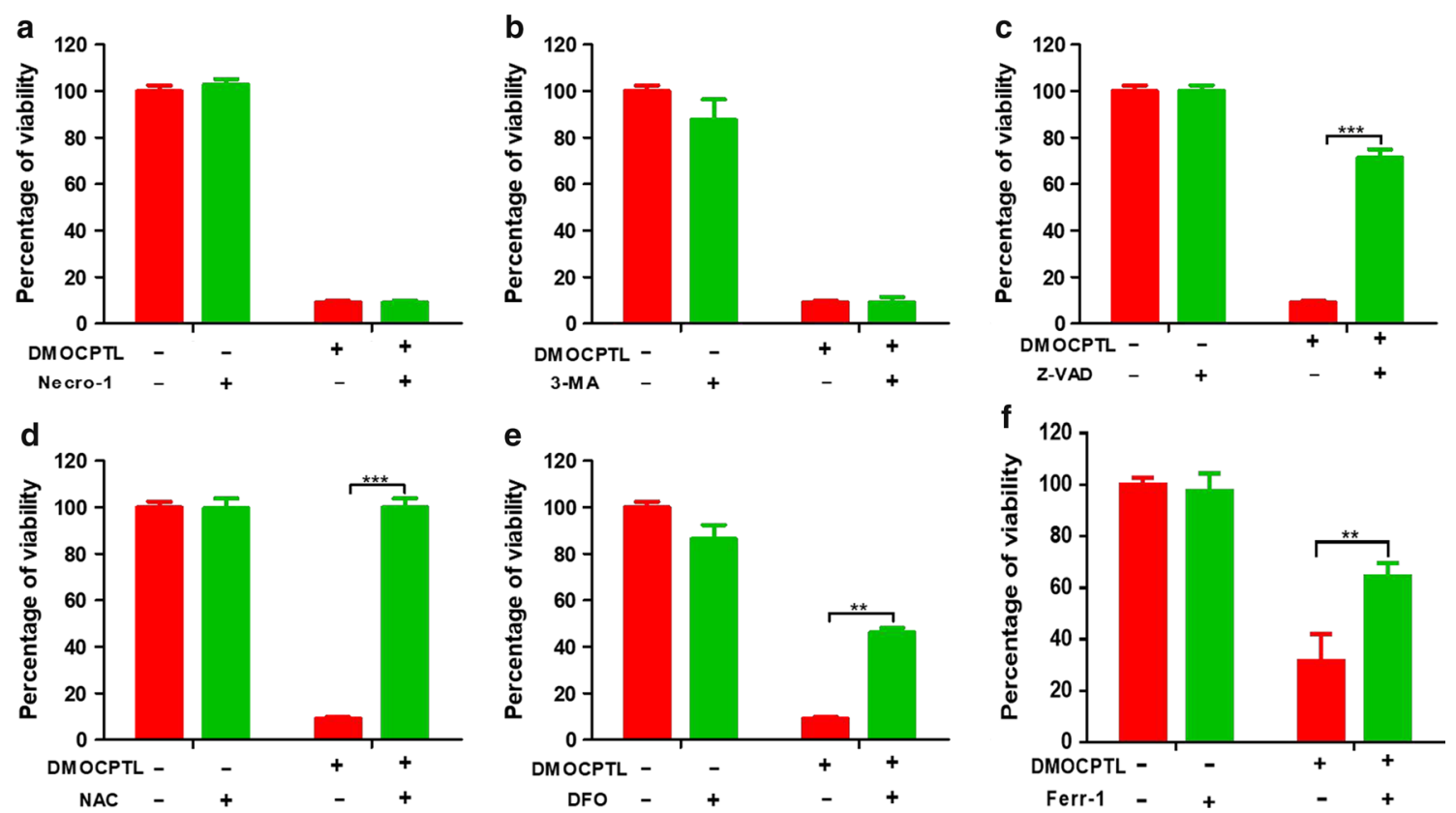

Fig. 3 DMOCPTL induced apoptosis and ferroptosis of TNBC cells. a The percentage of cell viability after the combination of DMOCPTL ( $0.5 \mu M)$ with necrosis inhibitor necrostatin-1 $(10 \mu \mathrm{M})$ for $72 \mathrm{~h}$. b The percentage of cell viability after the combination of DMOCPTL $(0.5 \mu \mathrm{M})$ with 3-methyladenine $(5 \mathrm{mM})$ for $72 \mathrm{~h}$. c The percentage of cell viability after the combination of DMOCPTL $(0.5 \mu \mathrm{M})$ with Z-VAD-FMK (10 $\mu \mathrm{M})$ for $72 \mathrm{~h}$. d The percentage of cell viability after the combination of DMOCPTL $(0.5 \mu \mathrm{M})$ with ferroptosis inhibitors N-Acetyl-L-cysteine ( $5 \mathrm{mM})$, e deferoxamine $(200 \mu \mathrm{M})$, and f Ferrostatin-1 $(10 \mu \mathrm{M})$. Analysis results represented mean $\pm S D,{ }^{* *} P<0.01,{ }^{* *} P<0.001$

the mechanism of DMOCPTL inducing apoptosis was studied by western blot assay. The relative levels of antiapoptotic proteins $\mathrm{Bcl}-2$ and $\mathrm{Bcl}-\mathrm{xl}$ were decreased with a dose-dependent manner, while the relative level of apoptotic protein Bax was dramatically increased with a dose-dependent manner. $\mathrm{Bax}, \mathrm{Bcl}-2$ and $\mathrm{Bcl}-\mathrm{xl}$ were important mitochondrial proteins which regulated the release of cytochrome C. Moreover, DMOCPTL could lead to the release of the cytochrome $C$ and the cleavage of caspase 9, caspase 3 and PARP, which induced apoptosis of MDA-MB-231 cells. These results suggested that DMOCPTL could induce apoptosis of MDA-MB-231 cells by mitochondria pathway (Fig. 4c, d).

We then investigated the mechanism of DMOCPTL inducing cell ferroptosis. The accumulation of intracellular ROS was increased after the treatment of DMOCPTL in a time- and dose-dependent manner (Fig. 4e-h). The lipid ROS, a key characteristic of ferroptosis, was increased synchronously after the treatment of DMOCPTL in a time- and dose-dependent manner (Fig. 4i, j). Moreover, we detected the $\mathrm{Fe}^{2+}$ intensity, the results showed that $\mathrm{Fe}^{2+}$ intensity was significantly increased (PGSK intensity decreased) after the treatment of DMOCPTL for $48 \mathrm{~h}$ (Fig. 4k, l). These above investigations suggested that DMOCPTL could induce apoptosis and ferroptosis of TNBC cells.
DMOCPTL reduced GPX4 protein level by inducing GPX4 ubiquitination

It is well known that GPX4 was a significant negative regulator of ferroptosis $[32,33]$. Western blot results showed that the protein level of GPX4 was highly expressed in MDA-MB-231, SUM159 and MDA-MB-468 cells (Fig. 5a). DMOCPTL could reduce GPX4 protein level in a dose-dependent manner in both MDA-MB-231 and SUM159 cells (Fig. 5b, c). Moreover, the flow cytometry assay and immunofluorescence assay also suggested that DMOCPTL down-regulated the level of GPX4 with a dose-dependent manner (Fig. 5d, e).

Ubiquitination is an enzymatic process that involves the binding of a ubiquitin protein to a substrate protein. The most common result of ubiquitination is the degradation of the protein via the proteasome. We rationalized that an alternative way to lead to cell death by inducing ferroptosis would be through inducing ubiquitination of GPX4. We treated MDA-MB-231 cells with proteasome inhibitor MG132 and the result showed that GPX4 was accumulated with the treatment of MG132. This result suggested that GPX4 was modified by ubiquitination and the degradation of GPX4 in MDA-MB-231 occurs via the ubiquitin-proteasome system (Fig. 5f). Co-immunoprecipitation analysis with anti-Ubiquitin antibody also indicated that GPX4 was ubiquitinated in MDA-MB-231 and 


\begin{abstract}
(See figure on next page.)
Fig. 4 DMOCPTL induced apoptosis and ferroptosis of TNBC cells. a The representative images of cell apoptosis in MDA-MB-231 cells for $48 \mathrm{~h}$ at different concentrations of $0.2 \mu \mathrm{M}, 0.5 \mu \mathrm{M}$ and $1 \mu \mathrm{M}$, respectively. $\mathbf{b}$ The statistical results of cell apoptosis assays. $\mathbf{c}$ Western blot analysis of caspase 9, cleaved caspase 9, caspase 3, cleaved caspase 3, PARP, and cleaved PARP after treatment of DMOCPTL for 48 h in MDA-MB-231 cells at different concentrations of $0.05 \mu \mathrm{M}, 0.1 \mu \mathrm{M}$ and $0.2 \mu \mathrm{M}$, respectively. $\mathbf{d}$ Western blot analysis of apoptosis related proteins of mitochondrial pathway after the treatment of DMOCPTL for $48 \mathrm{~h}$ in MDA-MB-231 at different concentrations of $0.05 \mu \mathrm{M}, 0.1 \mu \mathrm{M}$ and $0.2 \mu \mathrm{M}$, respectively. e The representative images and statistical results of ROS after the treatment of DMOCPTL with a dose-dependent manner for $2 \mathrm{~h}$ in MDA-MB-231 cells. f The representative images and statistical results of ROS after the treatment of DMOCPTL with a dose-dependent manner for $2 \mathrm{~h}$ in SUM159 cells. $\mathbf{g}$ The representative images and statistical results of ROS after the treatment of DMOCPTL with a time-dependent manner in MDA-MB-231 cells. $\mathbf{h}$ The representative images and statistical results of ROS after the treatment of DMOCPTL with a time-dependent manner in SUM159 cells. $\mathbf{i}$ The statistical results of lipid ROS after the treatment of DMOCPTL with a dose-dependent manner for $2 \mathrm{~h}$ in MDA-MB-231 and SUM159 cells. $\mathbf{j}$ The statistical results of lipid ROS after the treatment of DMOCPTL with a time-dependent manner for $2 \mathrm{~h}$ in MDA-MB-231 and SUM159 cells. $\mathbf{k}$ The representative images and statistical results of intracellular Fe ${ }^{2+}$ by PGSK assay after the treatment of DMOCPTL for $48 \mathrm{~h}$ in MDA-MB-231 cell. I The fluorescence intensity of PGSK after the treatment of DMOCPTL for $48 \mathrm{~h}$ in MDA-MB-231 cells by immunofluorescence assay. Analysis results represented mean $\pm \mathrm{SD},{ }^{*} P<0.05,{ }^{* *} P<0.01,{ }^{* * *} P<0.001$
\end{abstract}

SUM159 cells (Fig. 5g). Therefore, the ubiquitination of GPX4 after the treatment of DMOCPTL was analyzed. The result indicated that DMOCPTL could increase the ubiquitination of GPX4 with a dose-dependent manner (Fig. 5h). These data demonstrated that DMOCPTL could reduce GPX4 level by inducing ubiquitination of GPX4.

\section{DMOCPTL induced ubiquitination by directly binding to GPX4}

To further get understanding of the mechanism of DMOCPTL reducing level of GPX4, interaction of DMOCPTL with GPX4 was studied. DMOCPTL was docked with the GPX4 (PDB code: 5H5S). As shown the optimal pose of DMOCPTL oriented the styryl ring into the hydrophobic pocket, forming strong hydrophobic interactions with Trp163 and Pro182. Meanwhile, the oxygen atom of methoxyl group formed hydrogen bond with the side chain of Lys $162(3.41 \AA)$ and Ile156 (3.17 $\AA$ ) (Fig. 6a). DMOCPTL was tightly bound into the active site of GPX4, and the target binding site is consistent with Sakamoto's result [34]. The docking of DMOCPTL with GPX4 protein suggested that DMOCPTL may directly interact with GPX4. To further analyze the interaction of DMOCPTL with GPX4, we synthesized a series of DMOCPTL probes (Fig. 6d, e). The anti-TNBC activity showed that probe $\mathbf{8 a}$ showed a comparable $\mathrm{IC}_{50}$ value with that of DMOCPTL (Fig. 6b, c). Then, the in vitro pull-down experiment showed that DMOCPTL could bind with GPX4 directly in MDA-MB-231 and SUM159 cells (Fig. 6f, g). To better imitate the intracellular environment and membrane permeability of DMOCPTL, in situ pull-down assay was performed. The results also indicated that DMOCPTL could bind GPX4 directly in MDA-MB-231 and SUM159 cells (Fig. 6h, i). To further visualize the interaction of GPX4 and DMOCPTL, we synthesized a fluorescent probe 10a (Fig. 6j). The confocal microscopy results showed that DMOCPTL colocalized with GPX4 and ubiquitin (Fig. 6k). To further reveal the E3 enzymes involved in GPX4 ubiquitination induced by DMOCPTL, in situ pull down assay with probe 8a was performed (Fig. 6l).

\section{GPX4 was overexpressed in breast cancer}

GPX4 expression in breast cancer was still little investigated. To analyze GPX4 expression in breast cancer, we investigated the related functional states of GPX4 in CancerSEA (http://biocc.hrbmu.edu.cn/CancerSEA/). GPX4 expression distribution with $\mathrm{t}$-SNE showed that breast cancer cells with high GPX4 expression tended to cluster together in two patients (Fig. 7b, d), which suggests that GPX4 may promote the malignant progression of breast cancer. Furthermore, apoptosis, hypoxia, invasion, cell cycle and DNA damage were significantly related to GPX4 expression in breast cancer cells (Fig. 7a, c, e, $\mathrm{f}, \mathrm{g}, \mathrm{h}, \mathrm{i}$ ). The IHC assay showed that GPX4 protein was significantly increased in breast cancer tissue compared with normal breast tissue and related with breast cancer stages, which indicated the prominent role of GPX4 in breast cancer (Fig. 7j, k). Moreover, the level of GPX4 was higher in TNBC than non-TNBC in clinical samples, which suggested that GPX4 was very significant for TNBC (Fig. 7l).

\section{GPX4 knockdown induced ferroptosis and apoptosis of TNBC cells}

To further investigated the role of GPX4 in TNBC cells, GPX4 protein was knocked down by siRNA. The number of colonies was clearly decreased after GPX4 knockdown in MDA-MB-231 and SUM159 cells (Fig. 8a). Moreover, knockdown of GPX4 by siRNA increased the accumulation of lipid ROS (Fig. 8b, c), the intensity of intracellular $\mathrm{Fe}^{2+}$ (Fig. 8d, e), and intracellular ROS (Fig. 8f).These 

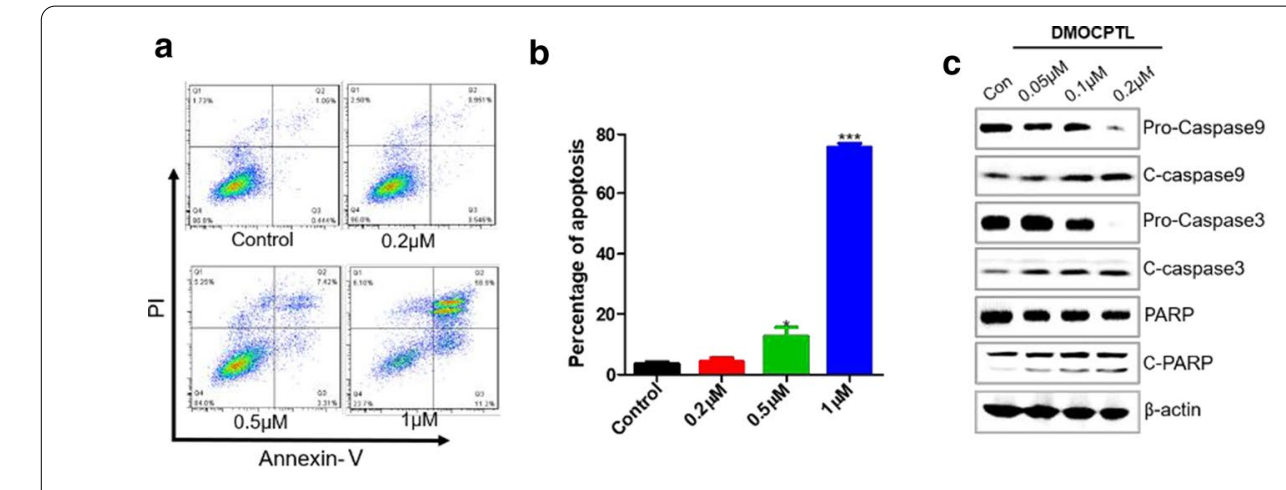

d
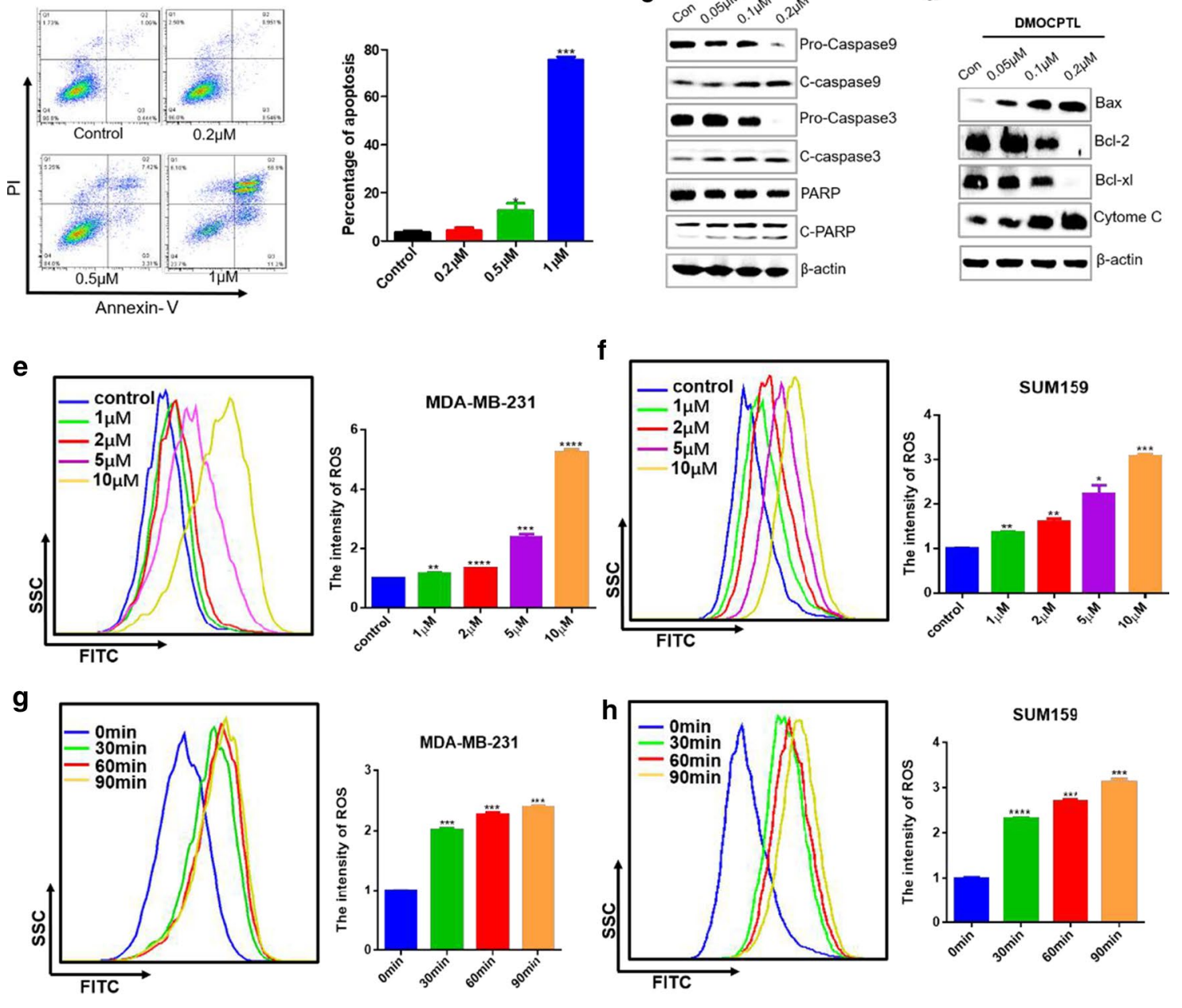

i
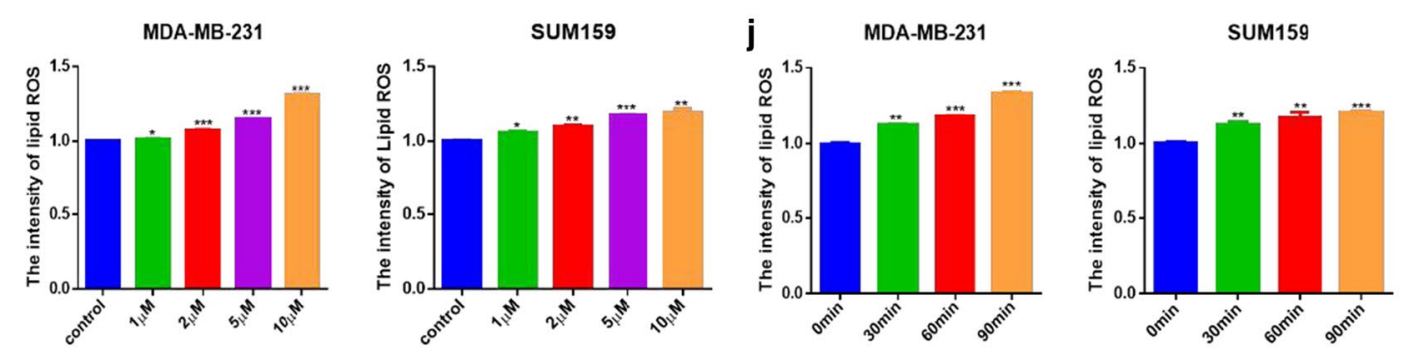

k
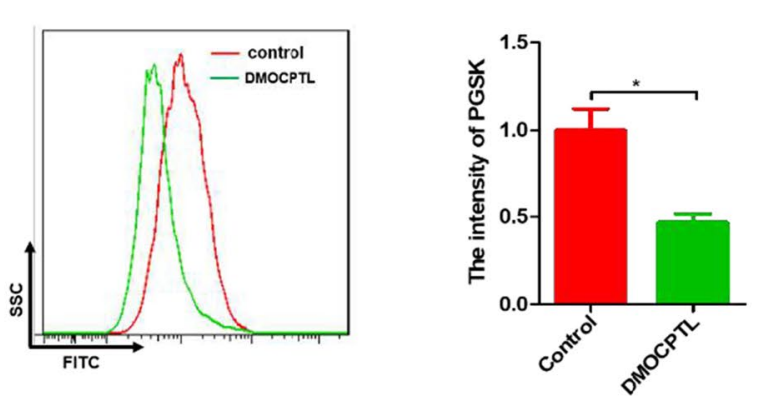

I
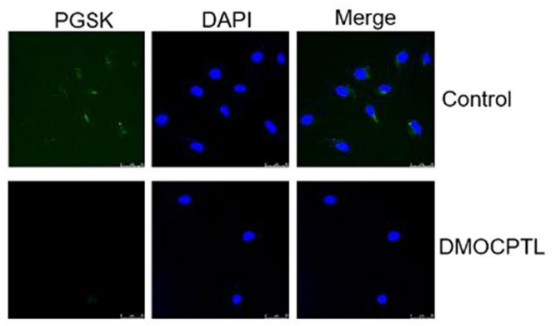


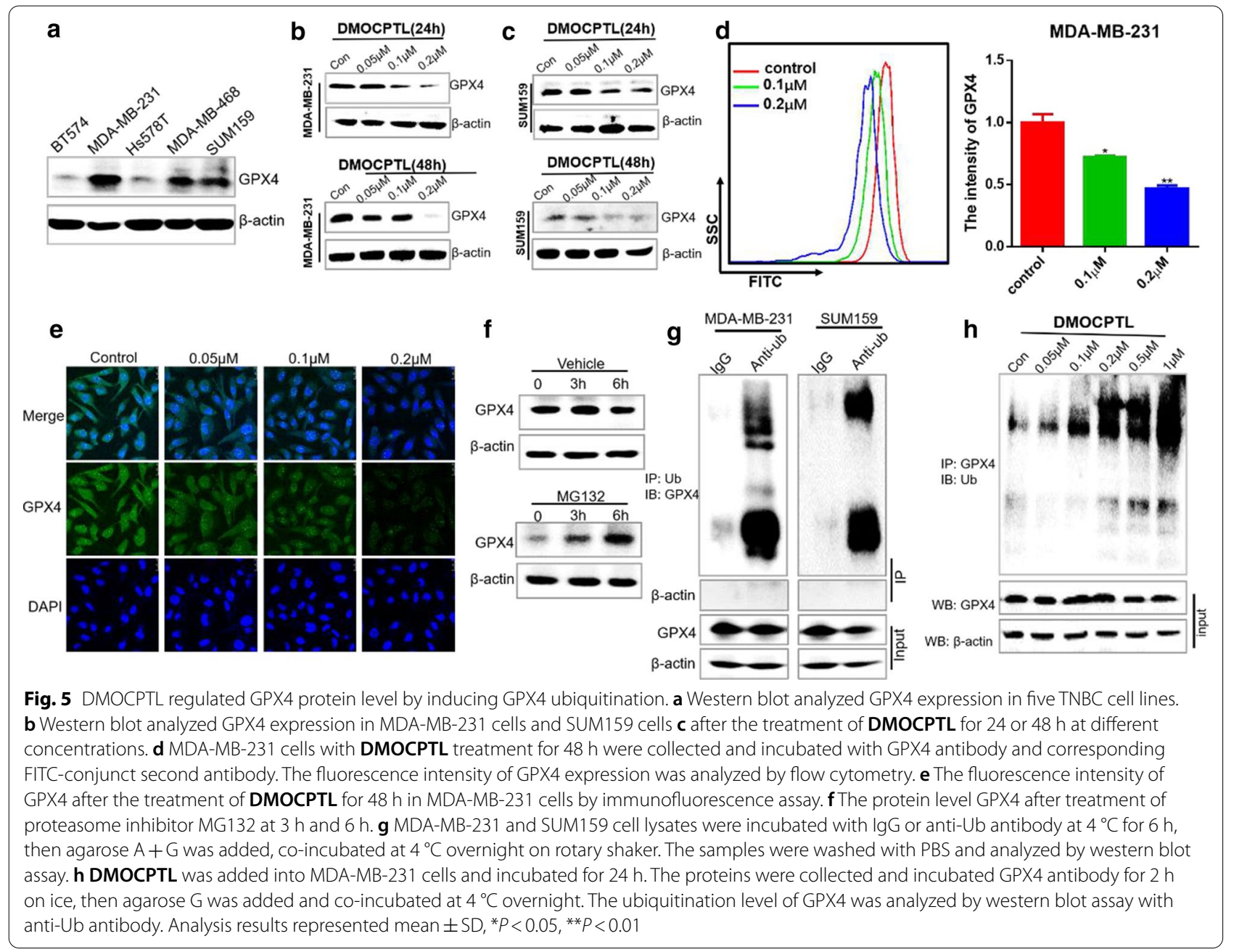

results demonstrated that GPX4 regulated ferroptosis in TNBC cells.

It was reported that knockdown of GPX4 induced apoptosis of glioma cells [32]. Accordingly, we speculated that GPX4 knockdown might induce apoptosis of breast cancer cells. To verify our speculation, we evaluated apoptosis related proteins by western blot assay. The results showed that the anti-apoptotic proteins Bcl-2 and Bcl-xl of GPX4-siRNA group were decreased, while the apoptotic protein Bax and Bim were dramatically increased compared with the control-siRNA group (Fig. 8g). Furthermore, the percentage of apoptosis induced by CCCP (an apoptosis inducer) was significantly increased after GPX4 knockdown (Fig. 8h, i). These results showed that GPX4 regulated ferroptosis and apoptosis in TNBC cells.

\section{GPX4 induced apoptosis through up-regulation of EGR1 in TNBC cells}

Early growth response-1 (EGR1) is an early response gene that is involved in growth, differentiation, apoptosis, neurite outgrowth, and wound healing [35]. As reported, EGR1 was closely related to cell apoptosis and ROS production. Moreover, ROS production induced EGR1 expression to induce cell apoptosis. GPX4 was a key regulator of ferroptosis by induced ROS especially lipid ROS production. Accordingly, we rationally speculated that GPX4 would induce EGR1 expression and cell apoptosis. We investigated the gene transcription level in breast cancer cells using the UALCAN database (http://ualcan.path.uab.edu/ index.html). EGR1 was significantly decreased in breast cancer tissues compared to normal breast tissues (Fig. 9a), and EGR1 gene expression was negative correlation with breast cancer stages (Fig. 9b). Moreover, the IHC assay showed that the EGR1 protein expression in breast cancer tissue was clearly decreased compared with that in normal breast tissue (Fig. 9c). To verify the effect of EGR1 in 


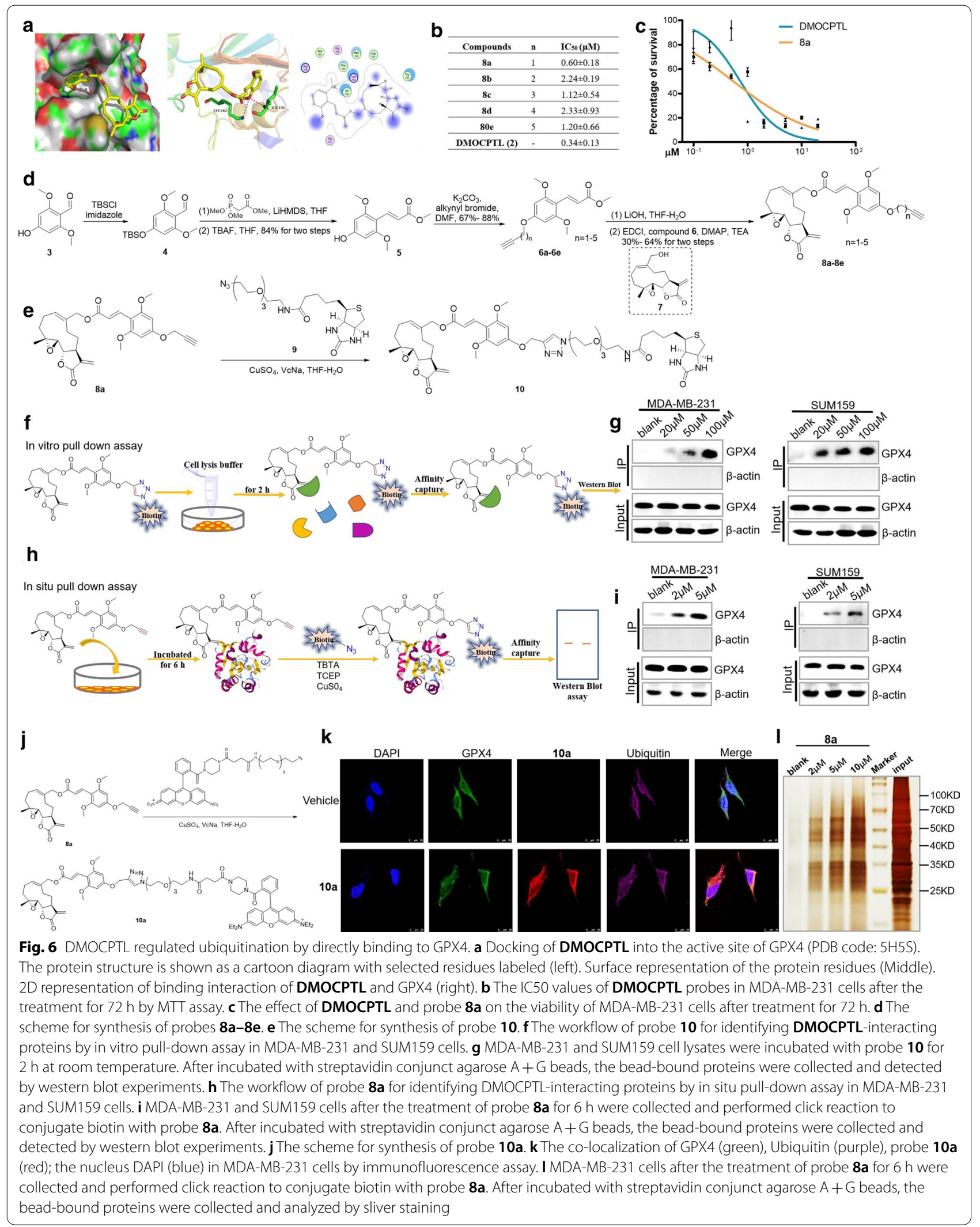




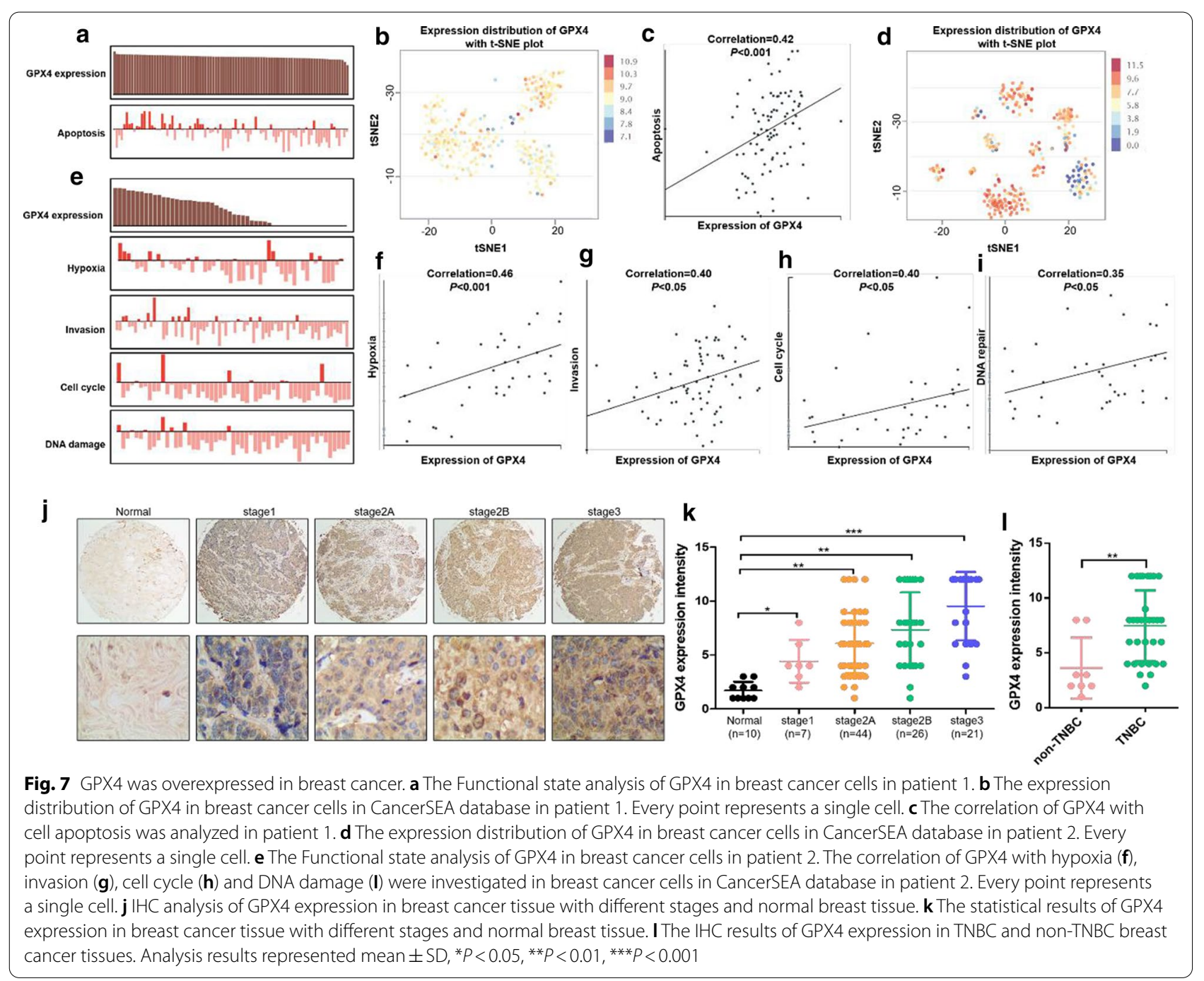

(See figure on next page.)

Fig. 8 GPX4 knockdown induced cell ferroptosis and apoptosis of breast cancer cells. a The representative pictures and statistical results of colony formation in MDA-MB-231 and SUM159 cells after GPX4 knockdown. b MDA-MB-231 cells were transfected with GPX4 siRNA for 48 h, and then cells were collected and incubated with BODIPY for $1 \mathrm{~h}$ to detect the lipid ROS level by flow cytometry. The representative images (left) and statistical results (right) of lipid ROS after GPX4 knockdown. c The representative images (left) and statistical results (right) of lipid ROS after GPX4 knockdown in SUM159 cells by flow cytometry assay. d MDA-MB-231 cells were transfected with GPX4 siRNA for $48 \mathrm{~h}$, and then cells were collected and incubated with PGSK for $1 \mathrm{~h}$ to detect intracellular Fe ${ }^{2+}$ level by flow cytometry. The representative images (left) and statistical results (right) of intracellular Fe ${ }^{2+}$ after GPX4knock down in MDA-MB-231 cells by PGSK assay. e The representative images (left) and statistical results (right) of intracellular $\mathrm{Fe}^{2+}$ after GPX4 knock down in SUM159 cells by flow cytometry assay. $\mathbf{f}$ MDA-MB-231 cells were transfected with GPX4 siRNA for $48 \mathrm{~h}$, and then cells were collected and incubated with DCF-DA for $1 \mathrm{~h}$ to detect ROS level by flow cytometry. The representative images (left) and statistical results (right) of ROS after GPX4 knockdown. $\mathbf{g}$ Western blot analysis of apoptosis related proteins of mitochondrial pathway after GPX4 knockdown. $\mathbf{h}$ The representative images of cell apoptosis in MDA-MB-231 and SUM159 cells after GPX4 knockdown with the treatment of CCCP. $\mathbf{i}$ The statistical results of cell apoptosis in MDA-MB-231 and SUM159 cells after GPX4 knockdown with the treatment of CCCP. Analysis results represented mean $\pm \mathrm{SD},{ }^{*} P<0.05,{ }^{* *} P<0.01,{ }^{* * *} P<0.001$

mitochondria-mediated apoptosis of TNBC cells, western blot assay was performed. The relative levels of antiapoptotic proteins Bcl-2 and Bcl-xL were increased, while the relative level of apoptotic protein Bax was dramatically decreased after EGR1 knockdown (Fig. 9d). Furthermore, EGR1 protein was significantly increased after GPX4 

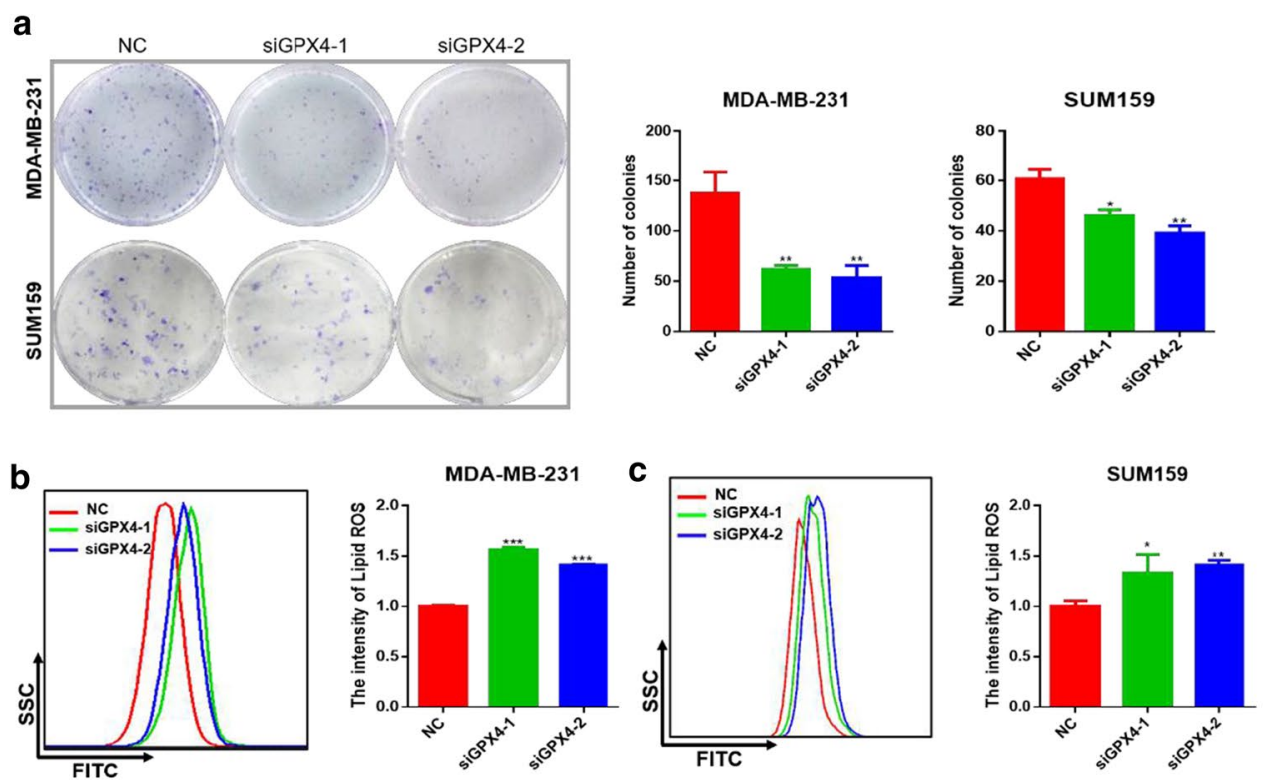

d

e
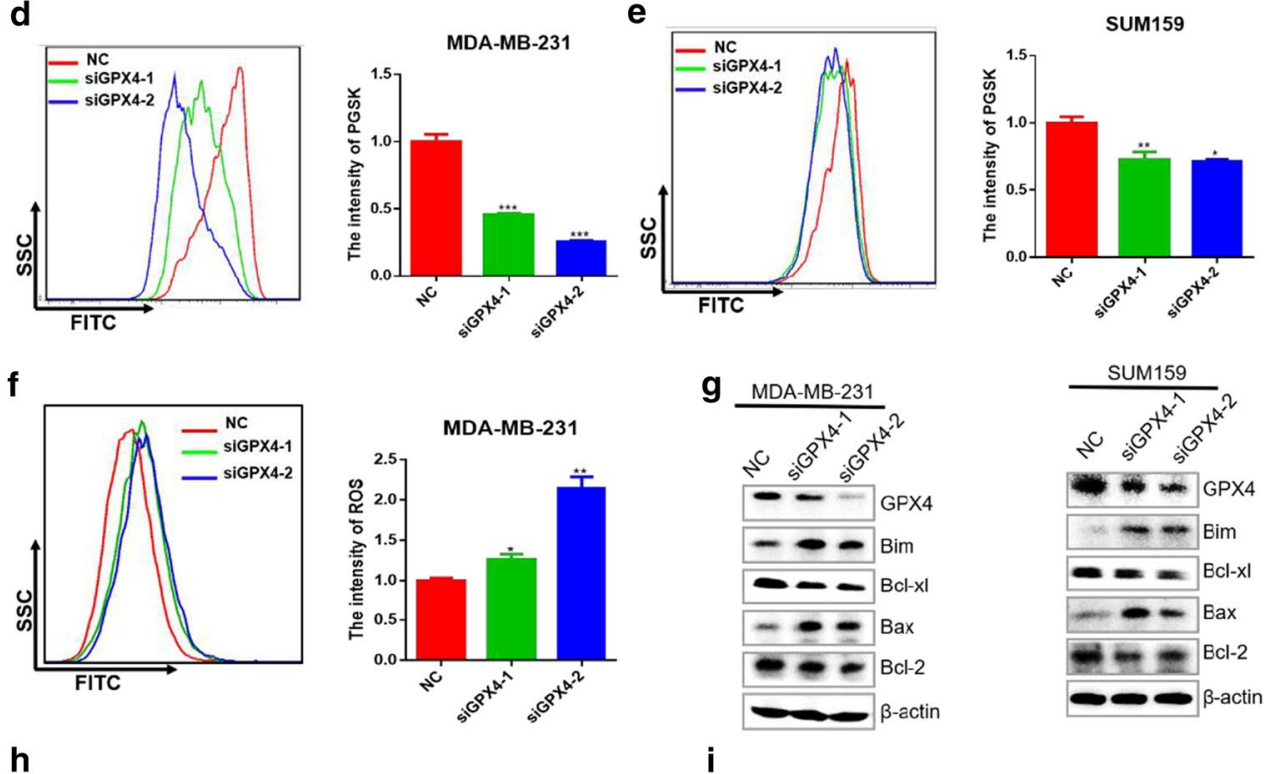

\section{h}
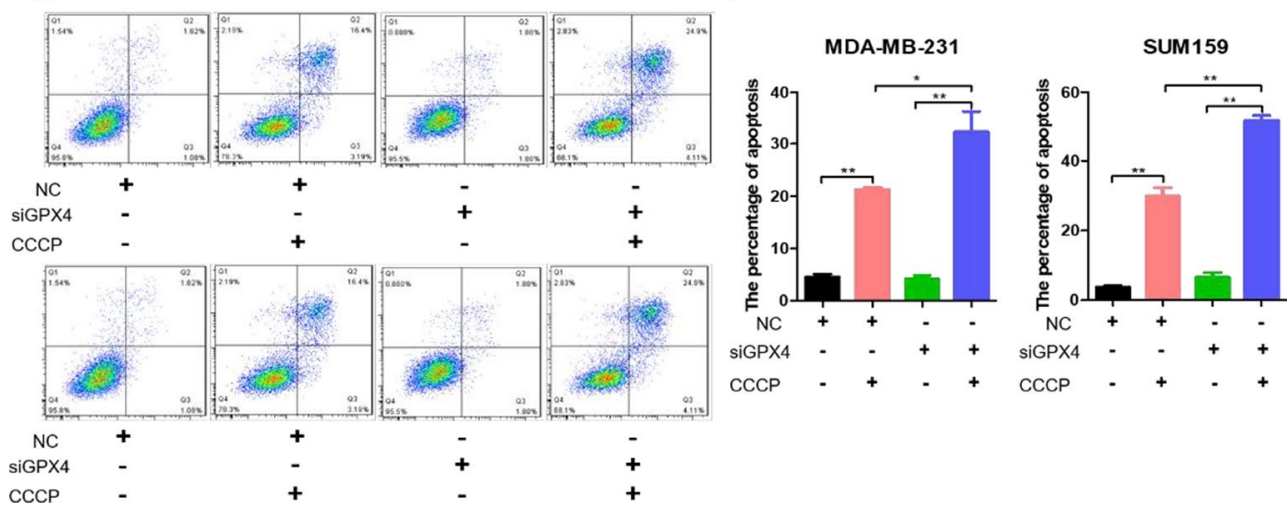

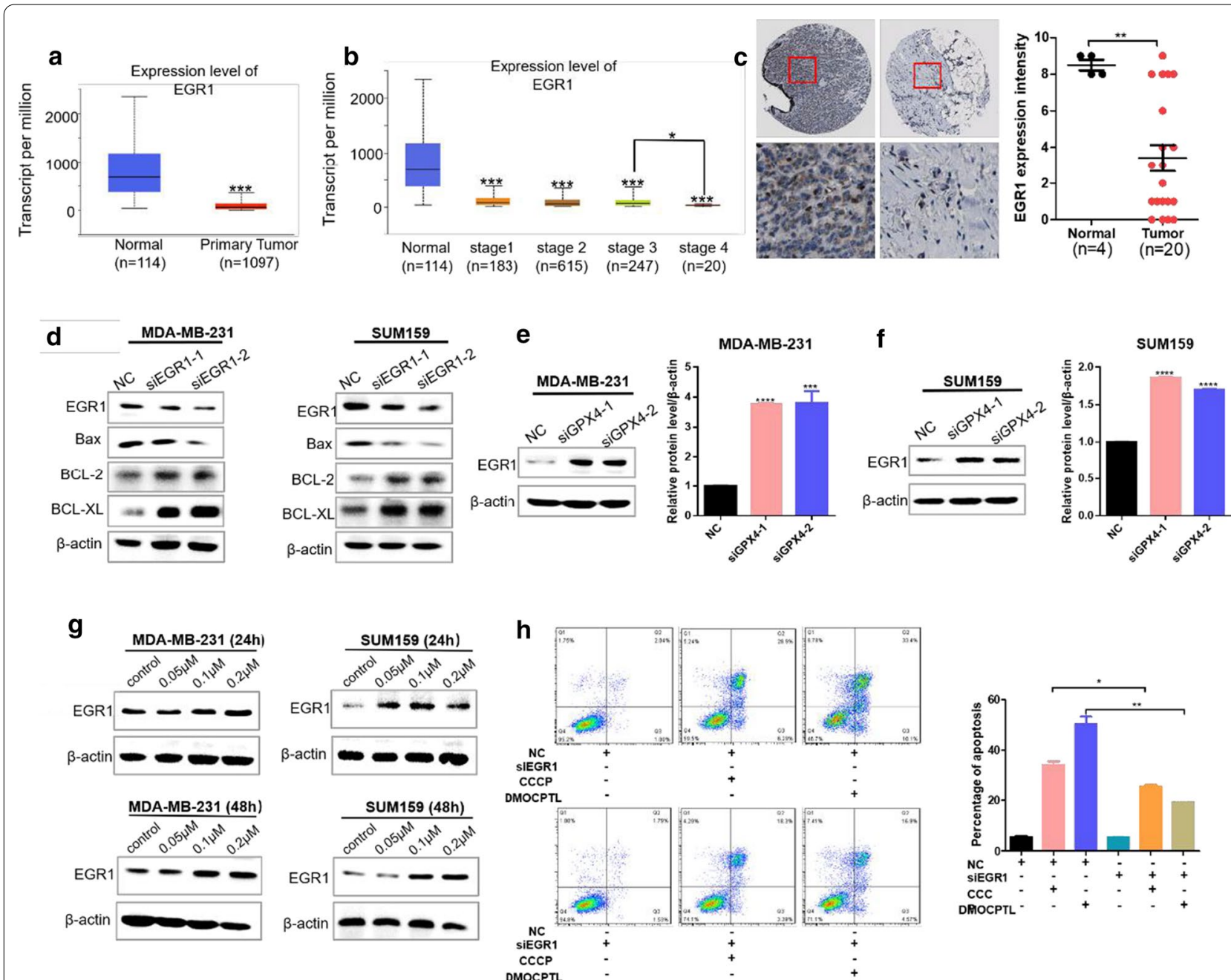

Fig. 9 GPX4 regulated apoptosis through upregulation of EGR1 in TNBC cells. a The expression analysis of EGR1 in normal individuals and breast cancer tissues by UALCAN. $\mathbf{b}$ The expression analysis of EGR1 in breast cancer tissue with different stages and normal breast tissue by UALCAN. $\mathbf{c}$ The IHC analysis of EGR1 expression in breast cancer tissue and normal breast tissue in the human protein atlas datasets. $\mathbf{d}$ Western blot analysis of apoptosis related proteins of mitochondrial pathway after EGR1 knockdown. e Western blot analysis of EGR1 expression after GPX4 knockdown in MDA-MB-231 cells. $\mathbf{f}$ Western blot analysis of EGR1 expression after GPX4 knockdown in SUM159 cells. $\mathbf{g}$ Western blot analysis of EGR1 expression after DMOCPTL treatment for $24 \mathrm{~h}$ or $48 \mathrm{~h}$ in MDA-MB-231 cells (left) and SUM159 cells (right). $\mathbf{h}$ The representative images of cell apoptosis in MDA-MB-231 cells after EGR1 knockdown with the treatment of CCCP or DMOCPTL (left). The statistical results of cell apoptosis in MDA-MB-231 cells after EGR1 knockdown with the treatment of CCCP or DMOCPTL (right). Analysis results represented mean $\pm \mathrm{SD},{ }^{*} P<0.05,{ }^{* *} P<0.01,{ }^{* * *} P<0.001$

knockdown (Fig. 9e, f). DMOCPTL clearly increased EGR1 expression both in MDA-MB-231 and SUM159 cells with a dose dependent manner (Fig. 9g). Moreover, the percentage of apoptosis induced by CCCP (an apoptosis inducer) and DMOCPTL were significantly decreased after EGR1 knockdown (Fig. 9h), which indicated that EGR1 inhibited cell apoptosis and the apoptosis inducing effect of DMOCPTL was rescued by EGR1 knockdown.
DMOCPTL could inhibit growth of TNBC and prolong survival life of mice in vivo and had no obvious toxicity

Taking account of significant anti-TNBC activity of DMOCPTL in vitro and its novel mechanism inducing mitochondria-mediated apoptosis and ferroptosis through ubiquitination of GPX4, we planned to evaluate its potency to inhibit TNBC in vivo and investigate its effect on GPX4 and apoptosis related proteins in vivo. However, DMOCPTL showed low solubility in water. In order to improve the water solubility of DMOCPTL, we designed to convert DMOCPTL into a prodrug 13. Michael-type addition of 7 with dimethylamine gave 


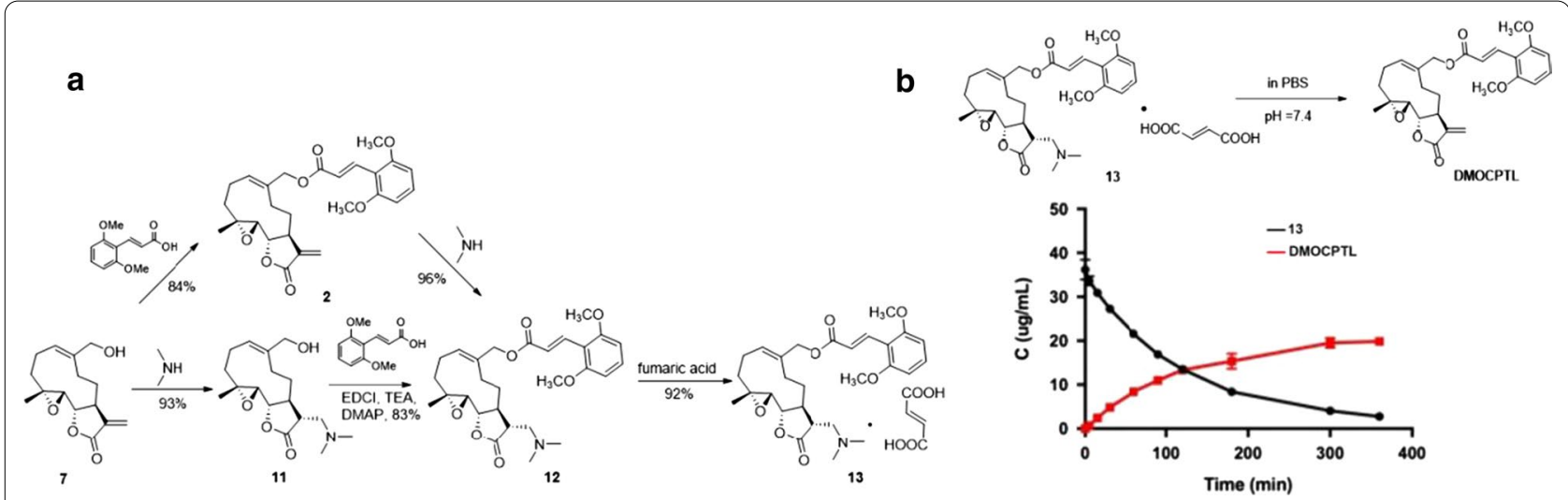

Fig. 10 The prodrug of DMOCPTL. a Schematic diagram for synthesis of compound 13, a prodrug of DMOCPTL. b Concentration-time curve of compound 13 and DMOCPTL in PBS $(\mathrm{pH}=7.4)$

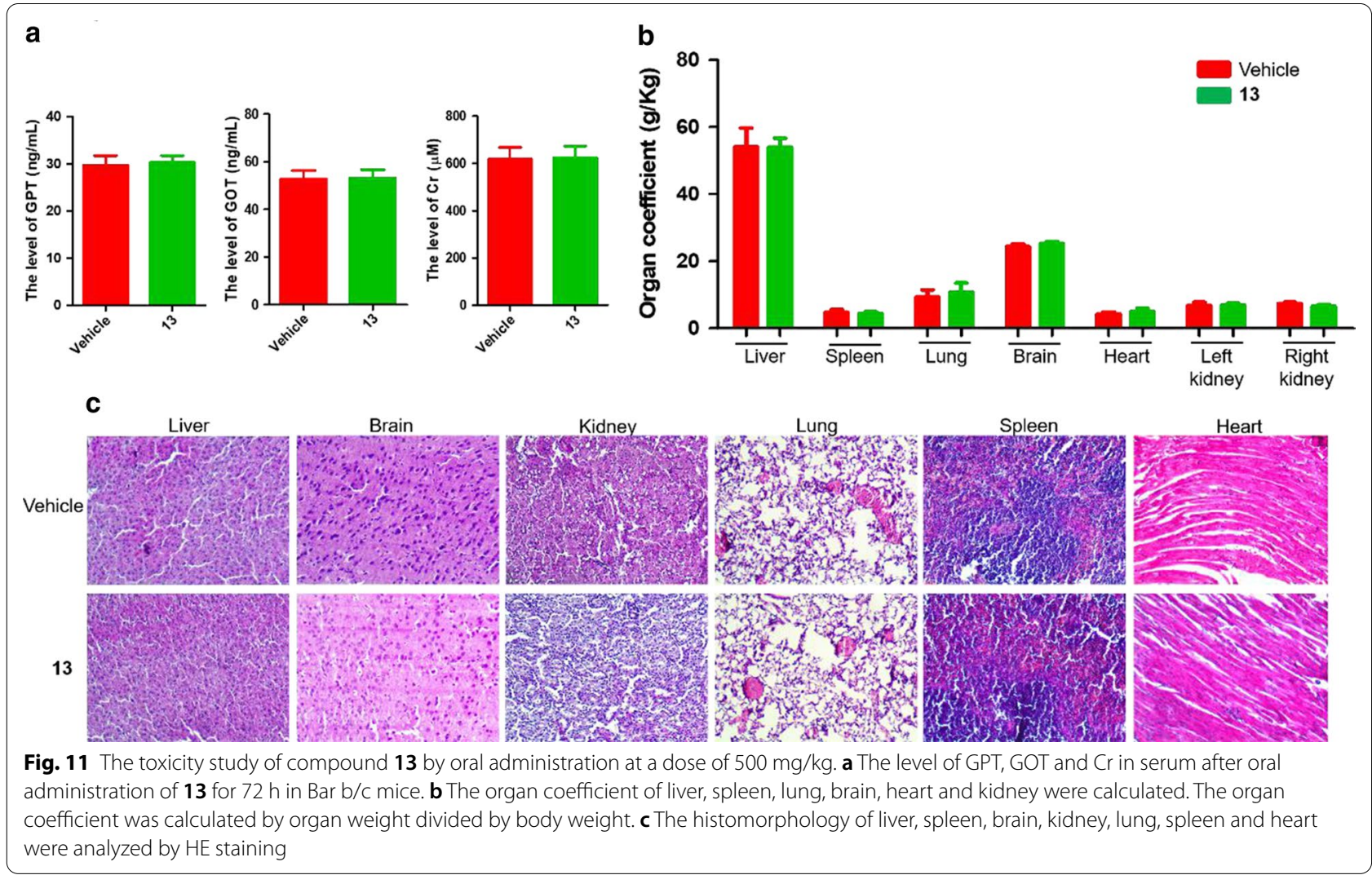

alcohol 11, subsequent EDCI/DMAP-mediated coupling with 2,6-dimethoxycinnamic acid produced ester 12. Alternatively, direct Michael addition of 2 selectively occurred on $\gamma$-butyrolactone moiety produced 12 without influence of the cinnamyl moiety. Finally, 12 and equivalent fumaric acid in methanol gave its salt 13 (Fig. 10a). Compound 13 could gradually release DMOCPTL in PBS solution ( $\mathrm{pH}=7.4$ ) (Fig. 10b).
To explore the safety of $\mathbf{1 3}$, compound 13 was administrated orally at a dose of $500 \mathrm{mg} / \mathrm{kg}$. The level of GPT, GOT and $\mathrm{Cr}$ in serum was detected, and no obvious change was observed comparing with that of vehicle control group (Fig. 11a). The weight and histomorphology of the major organs including liver, spleen, lung, kidney, heart, and brain in 13-group showed no obvious change compared with vehicle control group (Fig. 11b, c). 


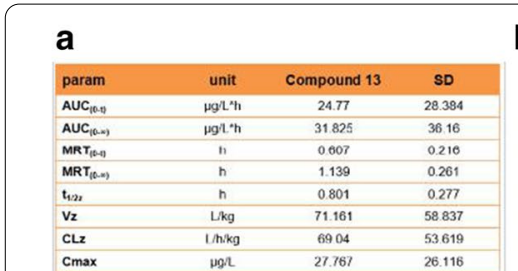
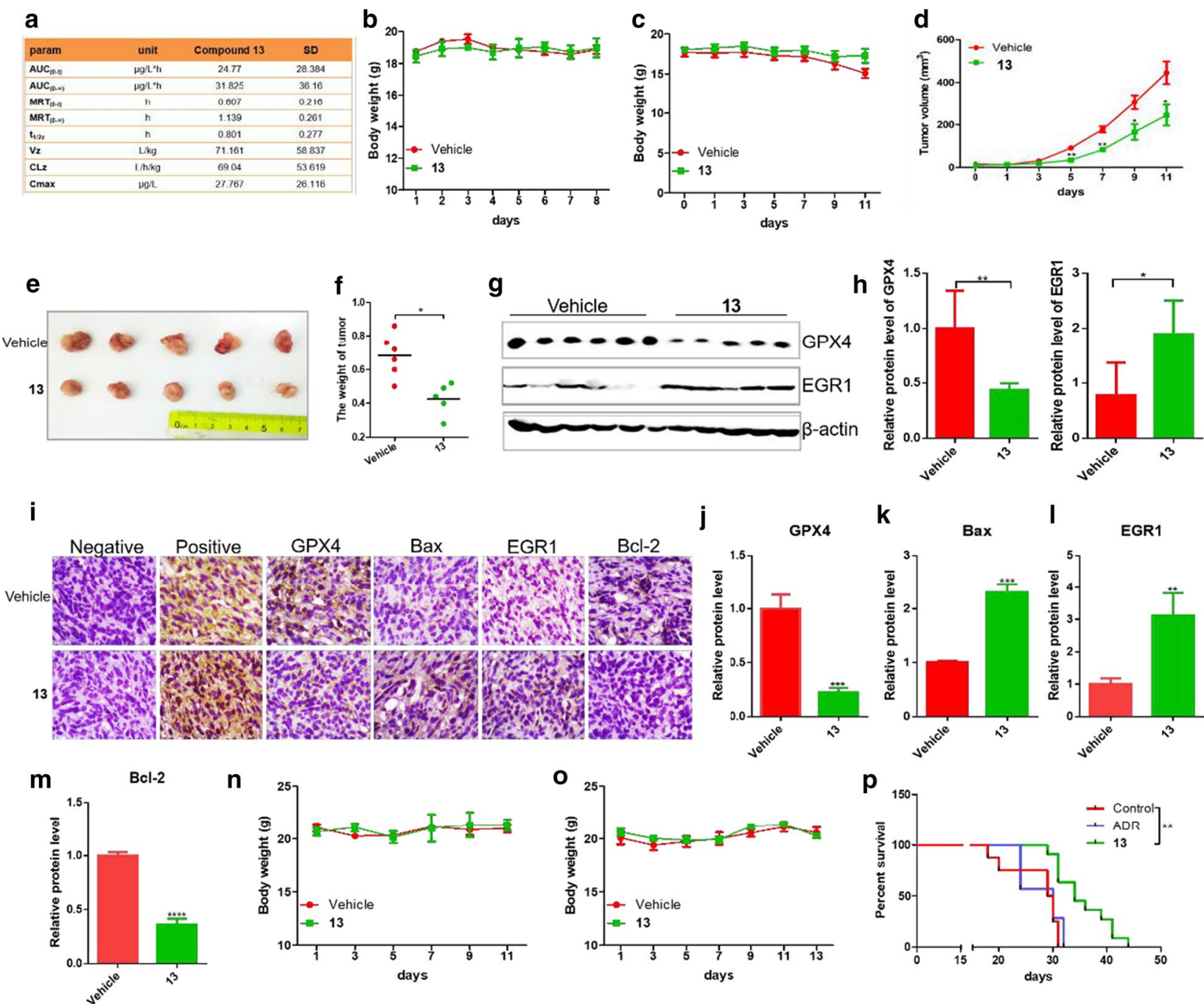

Fig. 12 DMOCPTL could inhibit TNBC and prolong survival life of mice in vivo and had no obvious toxicity. a Compound $\mathbf{1 3}$ was injected to $\mathrm{SD}$ rats by intravenous administration at a dose of $1 \mathrm{mg} / \mathrm{kg}$. Then, the blood sampling from jugular sinus of rats were collected at $2 \mathrm{~min}, 5 \mathrm{mins}$, 15 mins, 30mins, 1 h, $2 \mathrm{~h}, 3 \mathrm{~h}, 4 \mathrm{~h}, 6 \mathrm{~h}$ and $8 \mathrm{~h}$ after administration. The samples were treated and analyzed by LC/MS. The pharmacodynamics of $\mathbf{1 3}$ on SD rats was calculated by DAS 3.3. b The body weight of mice after intravenous administration of $\mathbf{1 3}$ at a dose of $50 \mathrm{mg} / \mathrm{kg}$ compared with vehicle group. $\mathbf{c}$ The body weight of mice after treatment of $\mathbf{1 3}$ at a dose of $7.5 \mathrm{mg} / \mathrm{kg}$ compared with vehicle group. $\mathbf{d}$ The statistical results of tumor volume after treatment of $\mathbf{1 3}$ at a dose of $7.5 \mathrm{mg} / \mathrm{kg}$. e The picture of tumors after administration of $\mathbf{1 3}$ compared with vehicle group. $\mathbf{f}$ The weight of tumors after the treatment of compound $\mathbf{1 3}$ compared with vehicle group. $\mathbf{g}$ The levels of GPX4 and EGR1 protein expression in tumors by western blot assay. $\mathbf{h}$ The statistical results of GPX4 and EGR1 protein expression in tumors. $\mathbf{i}$ The IHC assay of GPX4, EGR1, and mitochondria-mediated apoptosis related proteins Bax and BCl-2 in tumors. PBS instead of primary antibody was used as negative control. Breast cancer marker MUC16 was used as positive control. $\mathbf{j}$ The statistical results of GPX4, Bax (k), EGR1 (I) and BCl-2 (m) by IHC assay after $\mathbf{1 3}$ treatment. $\mathbf{n}$ The body weight of mice after oral administration of $\mathbf{1 3}$ at a dose of $500 \mathrm{mg} / \mathrm{kg}$. $\mathbf{o}$ The body weight of mice during treatment of $\mathbf{1 3}$ at a dose of $50 \mathrm{mg} / \mathrm{kg}$ every other day compared with vehicle group. $\mathbf{p}$ The statistical results of survival life after treatment of $\mathbf{1 3}$ at a dose of $50 \mathrm{mg} / \mathrm{kg}$ and clinically used drug ADR as a positive control by intraperitoneal administration at a dose of $2 \mathrm{mg} / \mathrm{kg}$ every 2 days. Analysis results represented mean $\pm S D,{ }^{*} P<0.05,{ }^{* *} P<0.01$

The pharmacodynamics of $\mathbf{1 3}$ was also investigated, and the results are shown in Fig. 12a. To further identify the safety of 13 , acute toxicity assay was performed. Bar b/c mice were treated with 13 at a dose of $50 \mathrm{mg} /$ $\mathrm{kg}$ by intravenous injection or vehicle control for 7 days. No obvious toxic reaction and loss of body weight was observed after treatment of $\mathbf{1 3}$ (Fig. 12b). To determine the effect of compound $\mathbf{1 3}$ in vivo, orthotopic breast cancer mouse model was used. The 4T1 cells were implanted into the mammary fat pads of Bar b/c mice. After treatment of 13, the tumor sizes of mice and their body weights were monitored and recorded every 2 days. The 
results showed that compound $\mathbf{1 3}$ significantly inhibited the tumor growth in vivo with no apparent loss of body weight compared with control group at the dose of $7.5 \mathrm{mg} / \mathrm{kg}$ (Figs. 12c-e). The tumor weight was also significantly reduced after treatment of compound 13 compared with control group (Fig. 12f). The protein level of GPX4 in tumor was decreased significantly in compound 13-treated group compared with vehicle group (Fig. 12g, h). The relative level of EGR1 was dramatically increased in compound 13-treated group compared with vehicle group (Fig. 12g, h). The tumors were harvested for IHC staining. The IHC implied that $\mathbf{1 3}$ treatment markedly down-regulated the expression levels of GPX4 and Bcl-2, and up-regulated the expression levels of EGR1 and Bax (Fig. 12i-m).

Furthermore, we planned to study the efficacy of $\mathbf{1 3}$ by oral administration. Prior to the study of the anti-breast cancer efficacy in vivo, an acute toxicity study of $\mathbf{1 3}$ by oral administration was conducted in Bar b/c mice. A single oral administration of $\mathbf{1 3}$ at a dose of $500 \mathrm{mg} / \mathrm{kg}$ was administered to the mice. These mice were observed for 14 days. During the study period, all mice remained alive, and no significant side effect was observed. The body weight of Bar b/c mice was not changed obviously (Fig. 12n). These results demonstrated that oral administration of $\mathbf{1 3}$ was well-tolerated in Bar b/c mice at a dose of $500 \mathrm{mg} / \mathrm{kg}$ in course of treatment and during the posttreatment period. After the oral administration of $\mathbf{1 3}$ with $50 \mathrm{mg} / \mathrm{kg}$ for 6 times every other day, no apparent change of the body weight was observed in comparison with vehicle group (Fig. 12o). The overall survival assay showed that compound $\mathbf{1 3}$ could significantly prolong the life span compared with control group. These results indicated that compound $\mathbf{1 3}$ could prolong survival life of mice in vivo and had no obvious toxicity (Fig. 12p).

The above results indicated that compound 13 was efficacious in inhibiting the growth of breast tumor and prolonging of survival span of mice in vivo and no obvious toxicity was observed.

\section{Discussion}

TNBC is the most malignant breast cancer among various breast cancer subtypes. Its prognosis is far from satisfactory. TNBC remains a very challenging disease. There is an urgent and unmet need to discover effective drugs with novel mechanism for treatment of TNBC [36]. Induction of ferroptosis is a new effective strategy for treatment of TNBC [19-23]. GPX4 is an essential regulator of ferroptotic cell death [29]. Small molecule ferroptosis inducers could be summarized into two classes: one directly acts on mitochondrial VDAC2/3, inhibits cystine uptake by system $\mathrm{Xc}^{-}$and ultimately results in lipid ROS accumulation in an NADH-dependent manner, including
Erastin and RSL5, the other directly inhibits GPX4 activity without decreasing GSH, including RSL3 [2]. In contrast to these mechanisms, it was reported that FINO2 could initiate ferroptosis through GPX4 inactivation and iron oxidation [37] and FIN56 induced ferroptosis by degrading GPX4 with requirement of the enzymatic activity of acetyl CoA carboxylase [38].

Here, we identify a derivative of PTL, DMOCPTL, as a potential anti-TNBC agent, which can induce ferroptosis and apoptosis through ubiquitination of GPX4. This is the first report of inducing ferroptosis through ubiquitination of GPX4 by binding to GPX4 directly. DMOCPTL could significantly inhibit the proliferation of TNBC cells and the inhibitory activity was evidently potent than its mother compound PTL. GPX4 played prominent role in breast cancer and was significantly increased in breast cancer tissue compared with normal breast tissue and related with breast stages. Moreover, the expression of GPX4 in TNBC was higher than non-TNBC, which indicated the significance of GPX4 in TNBC cells. The mechanism study suggested that DMOCPTL bound to GPX4 leading to ubiquitination of GPX4, which induced ferroptosis and EGR1-mediated apoptosis of TNBC cells. Previous study had indicated that the loss of GPX4 expression could induce apoptosis [33]. Moreover, Lu et al's study demonstrated that GPX4 knockdown could induce apoptosis of glioma cells [32]. However, the mechanism for GPX4 regulation of apoptosis is still obscure. Here, we firstly reveal that GPX4 regulated apoptosis through upregulation of EGR1 in TNBC cells (Figs. 8 and 9).

Acute toxicity study suggested that compound 13, the prodrug of DMOCPTL, showed no obvious toxicity by intravenous administration and oral administration at a dose of $50 \mathrm{mg} / \mathrm{kg}$ and $500 \mathrm{mg} / \mathrm{kg}$, respectively. Furthermore, in vivo experiment indicated that compound 13 effectively inhibited the growth of breast tumor and prolonged the life span of mice in vivo, and no obvious toxicity was observed during the experiment. The level of GPX4 was reduced, and EGR1 was increased in tumor for 13-treated group compared with vehicle group.

\section{Conclusions}

In summary, these findings indicated that DMOCPTL could induce ferroptosis and EGR1-mediated apoptosis of TNBC cells through ubiquitination of GPX4 (Fig. 13). This is the first report of inducing ferroptosis through ubiquitination of GPX4.Moreover, our results link GPX4 to EGR1 leading to apoptosis of TNBC cells. On basis of these investigations, we propose that compound $\mathbf{1 3}$ deserves further studies as a promising lead compound for discovery of novel anti-TNBC drug. 


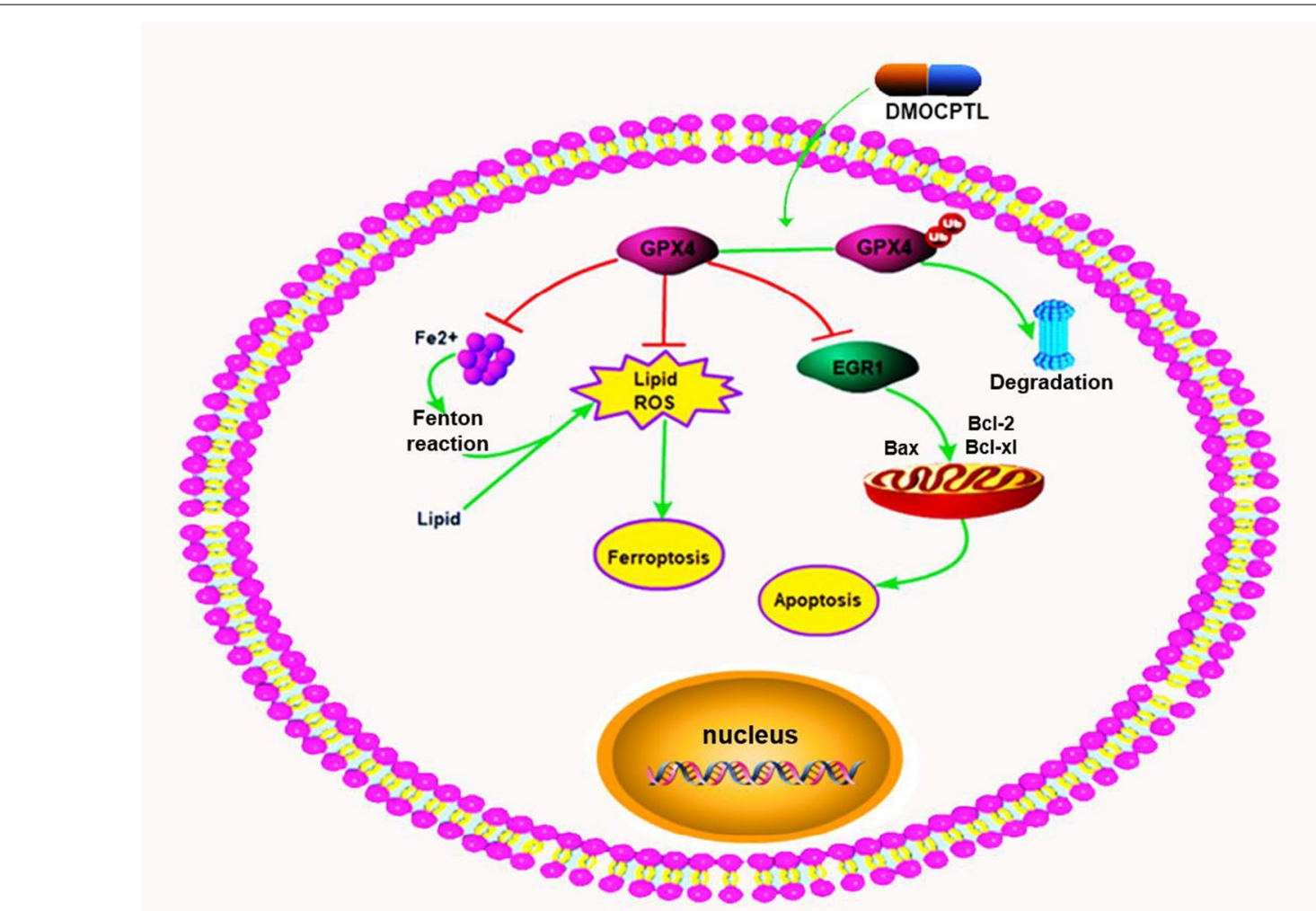

Fig. 13 Schematic diagram of our proposed model of mechanism for how small molecule DMOCPTL induced ferroptosis and apoptosis of TNBC cells

\section{Supplementary Information}

The online version contains supplementary material available at https://doi. org/10.1186/s13045-020-01016-8.

Additional file 1. NMR copies of compounds.

\section{Abbreviations}

PVL: Periventricular leukomalacia; DLBCL: Diffuse large B cell lymphomas; TNBC: Triple-negative breast cancer; ER: Estrogen receptors; PR: Progesterone receptors; HER-2: Human epidermal growth factor receptor 2; PTL: Parthenolide; AML: Acute myeloid leukemia; MTT: Thiazolyl blue tetrazolium bromide.

\section{Acknowledgements}

Not applicable.

\section{Authors' contributions}

Q.Z. and Y.C. designed research; Y.D., X.C., W.G., X.H., and M.W. performed research; Q.Z., Y.D., X.C., C.L., W.G., Q.W. and X.H. analyzed data; Q.Z. and Y.D. wrote and revised the paper. All authors read and approved the final manuscript.

\section{Funding}

This study was supported by the National Natural Science Foundation of China (NO. NO. 81872764 to Q.Z;; NO. 81903456 to Y.D.), The National Science Fund for Distinguished Young Scholars (NO. 81625021) to Y.C., Guangdong Joint Fund of the National Natural Science Foundation of China (NO. U1801288).
Availability of data and materials

All data generated or analyzed during this study are included either in this article or in Additional file 1.

Ethics approval and consent to participate

Not applicable.

\section{Consent for publication}

This manuscript has not been previously published and is not under consideration for publication elsewhere.

\section{Competing interests}

The authors declare no competing interests.

\section{Author details}

${ }^{1}$ State Key Laboratory of Medicinal Chemical Biology, College of Pharmacy and Tianjin Key Laboratory of Molecular Drug Research, Nankai University, Haihe Education Park, 38 Tongyan Road, Tianjin 300353, People's Republic of China. ${ }^{2}$ Accendatech Company, Ltd., Tianjin 300384, People's Republic of China.

Received: 24 July 2020 Accepted: 2 December 2020

Published online: 20 January 2021

\section{References}

1. Dixon SJ, Lemberg KM, Lamprecht MR, et al. Ferroptosis: an iron-dependent form of nonapoptotic cell death. Cell. 2012;149:1060-72.

2. Stockwell BR, Friedmann Angeli JP, Bayir H, et al. Ferroptosis: a regulated cell death nexus linking metabolism, redox biology, and disease. Cell. 2017:171:273-85. 
3. Yu H, Guo P, Xie X, et al. Ferroptosis, a new form of cell death, and its relationships with tumourous diseases. J Cell Mol Med. 2017;21:648-57.

4. XuT, Ding W, Ji X, et al. Molecular mechanisms of ferroptosis and its role in cancer therapy. J Cell Mol Med. 2019;23:4900-12.

5. Mou Y, Wang J, Wu J, et al. Ferroptosis, a new form of cell death: opportunities and challenges in cancer. J Hematol Oncol. 2019;12:34.

6. Xie Y, Hou W, Song X, et al. Ferroptosis: process and function. Cell Death Differ. 2016;23:369-79.

7. Shen Z, Song J, Yung BC, et al. Emerging strategies of cancer therapy based on ferroptosis. Adv Mater. 2018;30:e1704007.

8. Hassannia B, Vandenabeele P, Vanden BT. Targeting ferroptosis to iron out cancer. Cancer Cell. 2019:35:830-49.

9. Liang $C$, Zhang $X$, Yang $M$, et al. Recent progress in ferroptosis inducers for cancer therapy. Adv Mater. 2019;31:e1904197.

10. Friedmann Angeli JP, Krysko DV, Conrad M. Ferroptosis at the crossroads of cancer-acquired drug resistance and immune evasion. Nat Rev Cancer. 2019;19:405-14

11. Lu B, Chen XB, Ying MD, et al. The role of ferroptosis in cancer development and treatment response. Front Pharmacol. 2017;8:992.

12. Murphy MP. Metabolic control of ferroptosis in cancer. Nat Cell Biol. 2018;20:1104-5

13. Bray F, Ferlay J, Soerjomataram I, et al. Global cancer statistics 2018: GLOBOCAN estimates of incidence and mortality worldwide for 36 cancers in 185 countries. CA Cancer J Clin. 2018;68:394-424.

14. Siegel RL, Miller KD, Jemal A. Cancer statistics, 2018. CA Cancer J Clin. 2018;68:7-30.

15. Foulkes WD, Smith IE, Reis-Filho JS. Triple-negative breast cancer. N Engl J Med. 2010;363:1938-48.

16. Gluz O, Liedtke C, Gottschalk N, et al. Triple-negative breast cancer-current status and future directions. Ann Oncol. 2009;20:1913-27.

17. Penault-Llorca F, Viale G. Pathological and molecular diagnosis of triplenegative breast cancer: a clinical perspective. Ann Oncol. 2012;23(Suppl 6):vi19-22.

18. Denkert C, Liedtke C, Tutt A, et al. Molecular alterations in triplenegative breast cancer-the road to new treatment strategies. Lancet. 2017:389:2430-42.

19. Yu M, Gai C, Li Z, et al. Targeted exosome-encapsulated erastin induced ferroptosis in triple negative breast cancer cells. Cancer Sci. 2019;110:3173-82.

20. Yu $H_{\text {, Yang }} \mathrm{C}$, Jian $\mathrm{L}$, et al. Sulfasalazineinduced ferroptosis in breast cancer cells is reduced by the inhibitory effect of estrogen receptor on the transferrin receptor. Oncol Rep. 2019:42:826-38.

21. Ma S, Henson ES, Chen Y, et al. Ferroptosis is induced following siramesine and lapatinib treatment of breast cancer cells. Cell Death Dis. 2016; 7:e2307.

22. Hasegawa M, Takahashi $\mathrm{H}$, Rajabi $\mathrm{H}$, et al. Functional interactions of the cystine/glutamate antiporter, CD44v and MUC1-C oncoprotein in triplenegative breast cancer cells. Oncotarget. 2016;7:11756-69.
23. Chen MS, Wang SF, Hsu CY, et al. CHAC1 degradation of glutathione enhances cystine-starvation-induced necroptosis and ferroptosis in human triple negative breast cancer cells via the GCN2-eIF2alpha-ATF4 pathway. Oncotarget. 2017;8:114588-602.

24. Ghantous A, Sinjab A, Herceg Z, et al. Parthenolide: from plant shoots to cancer roots. Drug Discov Today. 2013;18:894-905.

25. Guzman ML, Rossi RM, Neelakantan S, et al. An orally bioavailable parthenolide analog selectively eradicates acute myelogenous leukemia stem and progenitor cells. Blood. 2007:110:4427-35.

26. Lesiak K, Koprowska K, Zalesna I, et al. Parthenolide, a sesquiterpene lactone from the medical herb feverfew, shows anticancer activity against human melanoma cells in vitro. Melanoma Res. 2010:20:21-34.

27. Nasim S, Crooks PA. Antileukemic activity of aminoparthenolide analogs. Bioorg Med Chem Lett. 2008;18:3870-3.

28. Zhang Q, Lu Y, Ding Y, et al. Guaianolide sesquiterpene lactones, a source to discover agents that selectively inhibit acute myelogenous leukemia stem and progenitor cells. J Med Chem. 2012;55:8757-69.

29. Yang WS, SriRamaratnam R, Welsch ME, et al. Regulation of ferroptotic cancer cell death by GPX4. Cell. 2014;156:317-31.

30. Araujo TG, Vecchi L, Lima P, et al. Parthenolide and its analogues: a new potential strategy for the treatment of triple-negative breast tumors. Curr Med Chem. 2020;27:6628-42.

31. Ge W, Hao X, Han F, et al. Synthesis and structure-activity relationship studies of parthenolide derivatives as potential anti-triple negative breast cancer agents. Eur J Med Chem. 2019;166:445-69.

32. Zhao H, Ji B, Chen J, et al. Gpx 4 is involved in the proliferation, migration and apoptosis of glioma cells. Pathol Res Pract. 2017:213:626-33.

33. Imai H, Nakagawa Y. Biological significance of phospholipid hydroperoxide glutathione peroxidase (PHGPx, GPx4) in mammalian cells. Free Radic Biol Med. 2003;34:145-69.

34. Sakamoto K, Sogabe S, Kamada Y, et al. Discovery of GPX4 inhibitory peptides from random peptide $T 7$ phage display and subsequent structural analysis. Biochem Biophys Res Commun. 2017;482:195-201.

35. Myung DS, Park YL, Kim N, et al. Expression of early growth response-1 in colorectal cancer and its relation to tumor cell proliferation and apoptosis. Oncol Rep. 2014;31:788-94.

36. Vagia $E$, Mahalingam $D$, Cristofanilli $M$. The landscape of targeted therapies in TNBC. Cancers (Basel). 2020:12:916.

37. Gaschler MM, Andia AA, Liu H, et al. FINO2 initiates ferroptosis through GPX4 inactivation and iron oxidation. Nat Chem Biol. 2018:14:507-15.

38. Shimada K, Skouta R, Kaplan A, et al. Global survey of cell death mechanisms reveals metabolic regulation of ferroptosis. Nat Chem Biol. 2016;12:497-503.

\section{Publisher's Note}

Springer Nature remains neutral with regard to jurisdictional claims in published maps and institutional affiliations.
Ready to submit your research? Choose BMC and benefit from:

- fast, convenient online submission

- thorough peer review by experienced researchers in your field

- rapid publication on acceptance

- support for research data, including large and complex data types

- gold Open Access which fosters wider collaboration and increased citations

- maximum visibility for your research: over 100M website views per year

At $\mathrm{BMC}$, research is always in progress.

Learn more biomedcentral.com/submissions 